\title{
Review
}

\section{Obesity, diabetes and the central nervous system}

\author{
D.Porte, Jr. ${ }^{1,4}$, R. J. Seeley ${ }^{3}$, S. C. Woods ${ }^{3}$, D. G. Baskin ${ }^{1,2,4}$, D.P. Figlewicz ${ }^{3,4}$, M. W. Schwartz ${ }^{1,4}$ \\ ${ }^{1}$ Department of Medicine, University of Washington, Seattle, Washington, USA \\ ${ }^{2}$ Department of Biological Structure, University of Washington, Seattle, Washington, USA \\ ${ }^{3}$ Department of Psychology, University of Washington, Seattle, Washington, USA \\ ${ }^{4}$ Division of Endocrinology and Metabolism, VA Puget Sound Health Care System, Seattle, Washington, USA
}

Nearly 25 years ago, one of us wrote a collaborative review entitled "Obesity and Diabetes, the Odd Couple" [1]. At that time we pointed out that obesity was a risk factor for diabetes mellitus, despite the fact that most obese people do not have and never will develop diabetes. We also pointed out that obesity is associated with insulin resistance and hyperinsulinaemia, whereas in the non-obese, diabetes is characterized by hypoinsulinaemia and hyperglycaemia. We asked, how is it that such different syndromes interact so closely? We concluded that while these two syndromes are likely to have independent risk factors and mechanisms, their known interactions made it likely that shared metabolic defects are involved in their pathogenesis. We concluded that further studies into the pathophysiology of these syndromes were needed to explain this apparently paradoxical association.

Corresponding author: Daniel Porte, Jr., M.D., Professor, Department of Medicine, University of Washington and Associate Chief of Staff for Research \& Development, VA Puget Sound Health Care System (151), 1660 S.Columbian Way, Seattle, WA 98108, USA

Abbreviations: 5-HT, serotonin, 5-hydroxytryptomine; $\alpha-1$, alpha-1; $\alpha-2$, alpha-2; $\alpha-\mathrm{MSH}$, alpha-melanocyte stimulating hormone; $\beta-1$, Beta-1; ATP, adenosine 51-triphosphate; CCK, cholecystokinin; CNS, central nervous system; CRH, corticotrophin-releasing hormone; CSF, cerebrospinal fluid; COS, African green monkey kidney cell-line; GLP-1, glucagon-likepeptide-1; glu, glutamine; GRP, gastric-releasing peptide; HPA, hypothalamic-pituitary-adrenal; IAPP, islet associated amyloid peptide; ICV, intracerebroventricular; IRS, insulin receptor substrate; ISF, interstitial fluid; JAK, Janus kinase; $\mathrm{K}_{\mathrm{m}}$, Michaelis-Mentor constant; LH, luteinizing; lys, lysine; MC, melanocortin; $\mathrm{MCH}$, melanin-concentrating hormone; mRNA, messenger ribonucleic acid; NPY, neuropeptide-Y; POMC, pro-opiomelanocortin; pro, proline; PVN, paraventricular; SNS, sympathetic nervous system; STAT, signal transducer and activator of transcription; UCP, uncoupling protein; $\mathrm{VMH}$, ventromedial hypothalamus.
In the intervening years, considerable advance has been made into the pathophysiology of both syndromes. First, it is now clear that hyperglycaemia in Type II (non-insulin-dependent) diabetes is not the result of a regulatory failure, but is an adaptive response to impaired beta-cell function and insulin resistance, and we have reviewed this extensively [2]. More recently, obesity has similarly been shown to result from a dysregulation of food intake and energy expenditure rather than a loss of control over food intake [3-5]. In either case the critical variable (blood glucose or body adiposity) is defended at an abnormal level due to a regulatory defect, and both hyperglycaemia and obesity have undesirable long-term metabolic and vascular complications. What is now apparent is that there is overlap among the hormones, neuropeptides, and receptors involved in these two disorders, and it is our belief that it is this sharing which plays a prominent role in their association.

In this article, we review our present understanding of the major elements of the feedback loops for body weight regulation in order to provide a comprehensive framework within which to place a torrent of new studies. We focus primarily on recent data implicating insulin, leptin, and hypothalamic neuropeptides as major elements. In this process we point out where the energy balance and glucose regulating systems intersect and indicate where common signalling mechanisms participate in their association. We conclude by synthesizing this information into a model that can explain how a single underlying set of pathophysiological factors can lead first to obesity and subsequently to Type II diabetes. 
There are eight key points about the energy balance system which we will develop:

1. Body weight (adiposity) is regulated by a classical negative feedback system involving the central nervous system (CNS).

2. The defended level of fuel stored in the form of adipose tissue is determined by the sum total of all of the genetic and environmental influences interacting on the system; therefore, there is no "set point" for adiposity which is "hardwired".

3. Afferent circulating signals originate from the endocrine pancreas, adipose tissue and the adrenal cortex, are hormones sensitive to energy balance, and regulate adipose tissue mass. They include insulin, leptin, and adrenal steroids.

4. Each of the circulating adiposity signals is regulated by factors in addition to body fat stores. Thus, there is no primary system which determines fat store size, and there is no apparent essential minimum or maximum adipose mass which can be maintained.

5. Afferent neural signals originate in the gut and liver in response to nutrients, are carried in the vagus, and regulate meal size, not adipose tissue mass.

6. CNS systems integrate the afferent neural and circulating information by modulating the activity of neuronal efferent pathways that utilize amines (including serotonin and catecholamines) and neuropeptides (including neuropeptide Y (NPY), corticotrophin releasing hormone $(\mathrm{CRH}), \alpha$-melanocortin $(\alpha-\mathrm{MSH}))$ and their receptors.

7. Effectors that determine energy balance include: a) food intake, largely by modifying meal size and b) energy expenditure in brown fat, liver, and muscle.

8. Obesity and cachexia are disorders of this regulatory system.

On the basis of this information, we hypothesize that obesity and Type II diabetes tend to occur together because carbohydrate metabolism and body weight regulation rely on common hormonal (insulin, leptin, adrenal steroids) and CNS (hypothalamic amine and neuropeptide) signalling systems.

\section{Anatomy of the regulated system for body adiposity and energy balance}

Our present model of body weight regulation is based on a negative feedback control system first proposed by Kennedy [6] in which the CNS plays a key role in determining food intake and energy expenditure in response to afferent signals which are generated in proportion to the size of the adipose tissue stores [5]. Some of these signals are produced by adipose tissue, but others are not. The three known adiposity-related signals, insulin, leptin, and adrenal steroids all circulate; and no afferent neural inputs appear to be in-

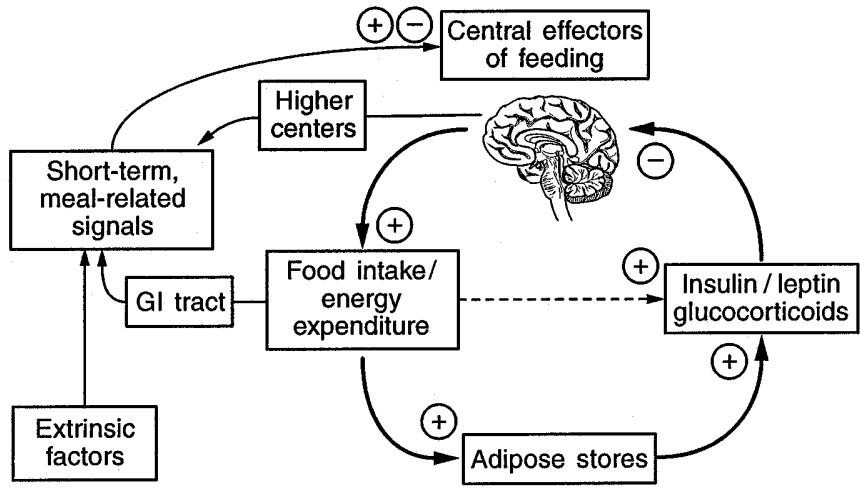

Fig. 1. Model for the regulation of energy balance with shortterm meal-related signals and long-term adiposity signals depicted

volved in this primary feedback loop. The CNS outputs are total caloric intake over a period of days to weeks and the rate of energy expenditure (Fig.1). In rodents, energy output can be influenced by sympathetic nervous system (SNS) control of facultative heat production in brown fat under the regulation of uncoupling protein-1 (UCP-1) [7, 8]. This molecule acts within mitochondria to uncouple oxidative phosphorylation such that fuel is oxidized to generate heat instead of ATP. In primates brown fat is largely limited to newborns. Until recently, it was believed that the only other way to regulate energy expenditure was through behavioural control of muscular exercise. However, the recent discovery of UCP-2 [9, 10] and UCP-3 [11] and their localization to other tissues such as muscle and liver in many species, including man, suggest that facultative energy expenditure may occur in all mammals. The net balance of caloric intake and energy expenditure over time determines the size of adipose tissue stores, which in turn strongly influences plasma concentrations of insulin and leptin. These hormones provide afferent input to the brain, thereby closing the feedback loop.

Superimposed on this primary feedback loop are short-term, meal-related signals to the CNS that modulate meal size, particularly by regulating the duration of individual meals. These signals come from afferent vagal fibers originating in the liver and gastrointestinal tract $[12,13]$ in association with peptide signals released from the gut [14]. Their influence on single meals (generally inhibitory, leading to meal termination) is integrated in the CNS with long-term body adiposity controllers so that single meal size varies according to the mass of the adipose tissue stores. This single meal system can be strongly influenced by learned behaviour and situational cues, resulting in great variability of single meal size. Despite this variability, there is great consistency in long-term caloric intake when measured over a period of days to weeks and this value matches average energy expenditure with remarkable precision in nor- 


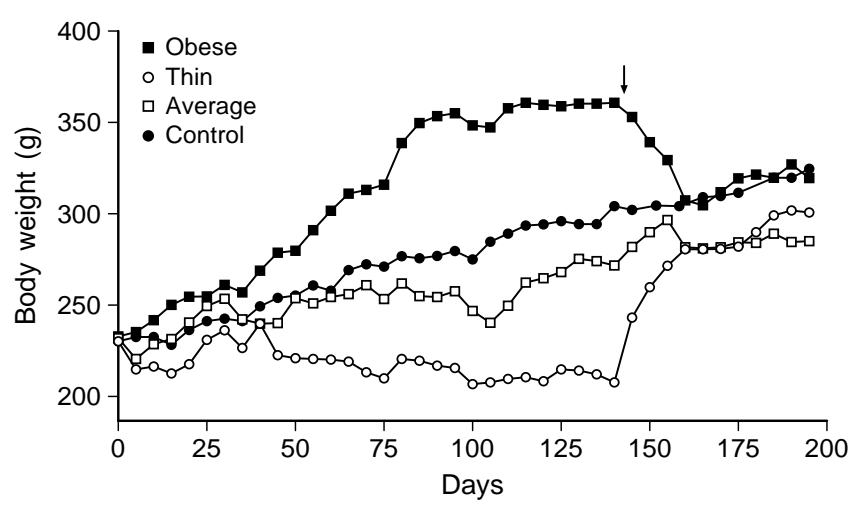

Fig. 2. Effect of tube feeding $50 \%$ excess (obese) and $20 \%$ deficit (thin) calories compared with pair-fed (average) and free feeding (control) animals on body weight. Tube feeding stopped at arrow $(\downarrow)$. Note subsequent loss or gain of weight in experimental groups to control values. (From ref. 25)

mal subjects [15-17]. Similarly, while food preferences can play a major role in caloric selection during a single meal, they have a limited impact on the ultimate regulation of body adiposity. It is important to point out that two of the three long-term energy balance signals (insulin and adrenal steroids) are critical to the regulation of carbohydrate metabolism and blood glucose, and recent data show that the third (leptin) probably influences beta-cell function [18, 19].

The operation of these feedback systems in man is evident in the clinic, and is easily demonstrated in the laboratory. A familiar clinical example is the outcome of the dietary reduction of body weight. Thus, behaviour modification [20, 21] and dietary programs [21-23] are often successful in achieving initial weight loss, but the high percentage of dieters who ultimately return to their baseline weight is impressive [22], and support the concept that a body adiposity regulatory process is activated by weight loss. When laboratory rats are either food-restricted or overfed for a long period of time, and then allowed to feed freely after weight loss or gain has occurred, restoration of adiposity to that of a free-feeding control animal follows quickly with little or no overshoot [15, 24, 25] (Fig. 2). Even when adipose tissue is surgically resected, fat tissue is replaced and restored to its original mass $[26,27]$. There is evidence that changes in both food intake and energy expenditure contribute to this return of fat mass. It has also been shown that brain lesions which produce obesity by damage to the hypothalamic ventromedial nucleus $(\mathrm{VMH})$ or leanness by damage to the lateral hypothalamic area (LH) [28] are still characterized by a regulated level of body weight (i.e. a tendency to return to the new elevated or lower weight when caloric excess or deficit is imposed and then free feeding is allowed), but at a level different from its original pre-lesion value. Thus, destruction of brain regions involved in energy balance does not cause regulatory failure, but a re-regulation of adiposity at a different level.

\section{Insulin}

Insulin was the first hormonal signal to be identified as a contributor to this regulatory process [3]. It was known for many years that insulin is secreted in proportion to adipose mass and that plasma levels change in response to excess and deficits of caloric intake [29]. Initially, there was resistance to the concept of insulin as a CNS regulator because of its inability to regulate glucose uptake in neural tissue. However, the discovery of high concentrations of insulin receptors on CNS neurons in areas important to food intake regulation in the hypothalamus of animals [30] and man [31] the finding that the hormone is present in cerebrospinal fluid (CSF) at concentrations proportional to circulating plasma levels $[32,33]$ suggested that circulating insulin enters the brain to regulate neuronal function independent of its ability to stimulate glucose uptake in peripheral tissues. Further studies of insulin action on neurons demonstrated pleotropic effects on ion flows [34], neurotransmitter uptake and release [35-39], cell growth, survival, and the transcriptional regulation of genes involved with differentiation [40, 41]. Tyrosine kinase activity of the CNS insulin receptor has been demonstrated [42], and one of its important second messengers, insulin-receptor substrate-1 (IRS-1), is present in hypothalamic neurons in the same regions that insulin receptors are found [43].

Entry of insulin into the CNS has been documented in many species $[3,44,45]$. Considerable evidence supports the concept of a specialized transport system facilitating its passage across the blood-brain barrier endothelium [44, 46, 47]. This transport has the characteristics of a saturable system with a $K_{m}$ value that is similar of that of the $\mathrm{k}_{\mathrm{d}}$ of the insulin receptor [48]. The uptake of insulin into CSF has been compared dynamically with that of inulin [44], a non-metabolizable marker of diffusion that is similar in molecular weight. When plasma insulin levels are clamped at an elevated value, the dynamic of insulin uptake is characterized by an initial time lag, followed by a continuous rise. This pattern of insulin uptake is characteristic of a solute that enters CSF after passing through an intermediate compartment that we have hypothesized to be brain interstitial fluid (ISF). This suggests that the route of CNS insulin uptake involves transport across the blood-brain barrier, diffusion throughout the neurophil ISF, and then entry into CSF. In contrast, when plasma inulin levels are clamped, CSF inulin rises rapidly and maximally at the beginning of a similar i.v. inulin infusion as would be expected for a direct transfer from plasma to CSF. 
Thus, inulin appears to enter CSF directly across the choroid plexus, similar to the kinetics of transport for electrolyte and water constituents of CSF [49]. Quantitative modelling of a two-compartment system closely fits inulin uptake, but a three-compartment system is needed to fit the dynamics of CSF insulin uptake [48]. Such a three-compartment model allows one to calculate some of the characteristics of the transfer process. The use of this model has led to several important conclusions.

First, CSF insulin levels are expected to be lower than those of brain ISF [48]. This is important because measured CSF insulin levels are only $1-2 \%$ of plasma, and are potentially lower than required to mediate a biological action of insulin in the brain [48]. Second, insulin receptors, despite their high concentration in the choroid plexus [50], are probably not used for transport, but are more likely to function as a mechanism for degrading CSF insulin and/or limiting access of plasma insulin into CSF through the choroid plexus $[44,47,51]$. Third, brain ISF insulin levels are estimated to be approximately $60 \%$ of plasma concentration at steady-state, in a range in which physiologic changes could have biological effects [48]. Fourth, blood-brain barrier transport of insulin is thought to be mediated by insulin receptors and subject to regulation [3]. We have shown that insulin uptake efficiency is reduced in the presence of adrenal steroid treatment of experimental animals [52], and found inefficient CSF uptake of plasma insulin in the Zucker fatty rat $(f a / f a)$ [53]. In this animal model, in which obesity results from an autosomal recessive mutation in the leptin receptor gene [54, 55], reduced insulin uptake efficiency is associated with a reduction of capillary insulin binding which could explain the inappropriately reduced CSF insulin levels of the $f a / f a$ rat [56]. It has been estimated that $80 \%$ of CNS insulin uptake is mediated through this transport mechanism at physiological circulating insulin concentrations [48]. Support for the involvement of insulin receptors in the transport process is provided by studies showing that endothelial cells bind to and internalize (but do not degrade) insulin $[46,57]$. Rather, they transport intact insulin via a mechanism that is blocked by insulin receptor antibody $[58,59]$. Use of the insulin receptor for blood-brain barrier transport in vivo is supported by the demonstration that proinsulin, a molecule similar to insulin but with a much lower affinity for the insulin receptor, is transported much less efficiently into CSF than insulin [47].

This blood-brain barrier insulin transport system is not necessarily the only mechanism by which circulating insulin has access to CNS neurons. For example, it is known that the circumventricular organs of the brain are supplied by a vasculature with a "leaky" blood-brain barrier, and that plasma solutes can diffuse relatively freely into these areas [49]. One of these areas, the median eminence, is bordered by the medial basal hypothalamus, a region rich in binding sites for insulin on neurons implicated in the regulation of food intake, such as those in the arcuate nucleus [60]. Thus, it is possible that diffusion of insulin into the median eminence from plasma facilitates access of circulating insulin to insulin receptors expressed by neurons in the arcuate nucleus, a region of critical importance to energy homeostasis.

One test of the hypothesis that insulin provides feedback inhibition of food intake is to infuse insulin into brain ventricles of chronically cannulated animals. Such studies have been done in rats [61-63], sheep [64], marmots [65], and non-human primates [66]. In each case, there is a dose-dependent depression of food intake which is slowly progressive over time; that is, there is no immediate suppression of a single meal but rather a suppression of 24 -h food intake. This effect requires several hours to become evident, and is maximal within 24-h to 7 days, depending on the dose and species studied. Similarly, the systemic infusion of insulin in rodents at small doses in which hypoglycaemia does not occur, or during a euglycaemic hyperinsulinaemic clamp in primates, causes a fall in food intake $[67,68]$. This anorexic effect of insulin is specific in the sense that there is no reduction of drinking or change in other behaviours such as sodium appetite or general activity. We have found that this regimen does not cause a conditioned taste response as would occur with illness [69]. If rodents are food-restricted to reduce body weight below that usually achieved by such an insulin infusion, and then receive an intracerebroventricular (ICV) insulin infusion during ad libitum food intake, the animals increase their food intake to raise body weight to the same value observed in non-food-restricted animals treated with the same insulin infusion [70]. Thus, insulin does not simply reduce food intake and body adiposity; it changes the level of weight that the animal defends under a particular set of physiological conditions.

The effect of insulin in the CNS to reduce food intake and body adiposity supports the conclusion that insulin is a central catabolic hormone that promotes a state of negative energy balance. Studies from the laboratories of Rothwell and Stock [71] have suggested that there is a parallel mechanism to increase energy expenditure by activating brown fat thermogenesis regulated by CNS insulin. They had found that dietary intake induced a meal-related thermogenic response which was an important component of the weight response to changes in macronutrient composition in rats. Further, they showed that this response was strain-dependent and contributed to the large variability in the weight gain response to palatable and/or high fat diets [72]. This action is different from insulin's well-known anabolic effects in peripheral tissues. Therefore, during a period of positive en- 


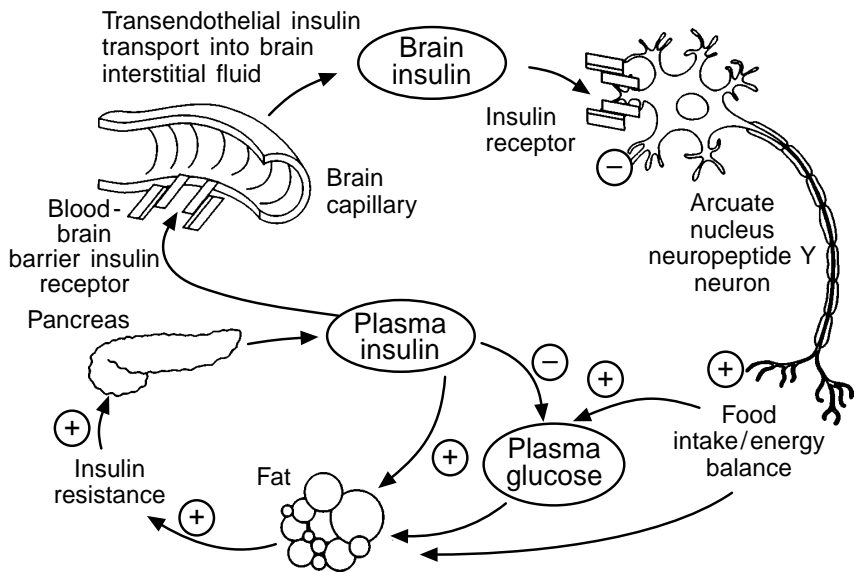

Fig.3. Diagrammatic view of the uptake and regulation of neuronal systems by circulating insulin

ergy balance induced by overfeeding, the rise in plasma insulin promotes fat storage through its peripheral anabolic actions, but simultaneously influences CNS regulatory sites to suppress food intake, increase energy expenditure, and limit weight gain (Fig.3). We have postulated that an important function of the hyperinsulinaemia that accompanies an increase of adipose mass is to limit further weight gain under conditions in which excess food intake results from an environmental event such as the provision of large amounts of a calorically dense, high-fat diet [73]. Under these conditions, the expansion of adipose stores should increase CNS insulin delivery, and inhibit food intake. Conversely, during a state of negative energy balance due to reduced food intake, the peripheral anabolic action of insulin is reduced and alternate non-carbohydrate sources of fuel are mobilized to meet energy needs. Simultaneously, food intake and appetite would be stimulated by central insulin deficiency, thereby facilitating the eventual restoration of body adiposity. In insulin-deficient diabetes, the central effects of insulin can explain the well-described clinical concomitant, hyperphagia. Thus, in hypoinsulinaemic states, peripheral insulin deficiency contributes to the wasting of peripheral tissues and consequent weight loss, while CNS insulin deficiency promotes compensatory hyperphagia which facilitates weight recovery.

This hypothesis was tested by replacing insulin in the brain of rats with streptozotocin-induced diabetes [74]. Under these conditions, hyperphagia was reduced, but there was no amelioration of the hyperglycaemia or weight loss. Hence, the peripheral and central consequences of hypoinsulinaemia are both needed to explain the polyuria, polydipsia, and the hyperphagia of the insulin-deficient state.

Despite this simple explanation and its experimental support, the observation that intensified insulin treatment to normalize blood glucose levels often causes unwanted weight grain has raised important questions for the insulin hypothesis. The explanation for this excess weight gain is complex and far from complete at the present time. However, in some instances food intake is not excessive during "tight" control of diabetes [75]. In this setting, it appears that the peripheral anabolic actions of insulin override its ability to suppress intake, with the net effect that weight increases despite lower food intake. Alternatively, recurrent bouts of hypoglycaemia, a powerful stimulus to food intake [76], may be another important contributor to this excess weight gain, since clinical hypoglycaemia is increased by at least a factor of three when intensified insulin treatment is used [75]. Thus, hypoglycaemia may override the suppressive CNS effect of insulin on food intake, and could rapidly expand adipose stores when combined with insulin's anabolic effect in peripheral tissues.

\section{Insulin, adiposity and diabetes}

This effect of insulin in the brain to suppress food intake has important implications for the effect of an increase in body adiposity to cause insulin resistance. The relationship between the size of the fat deposits and the development of insulin resistance is complex. Thus, deposits of the male or central pattern are associated with greater insulin resistance than deposits in the female or peripheral sites, particularly the lower body or buttock [77, 78]. While sex hormones obviously are important to this pattern variance, other factors are involved [79]. It is not known whether they are environmental (i.e. nutritional, climate, stress) [80], other hormones (cortisol is particularly suspect) [79, 80], and/or genetic [81, 82]. The number of obesity loci identified is large and growing [83], and therefore it is likely to be multifactorial. Intra-abdominal fat seems to be particularly important [84]. How this variation in fat deposition relates to longterm body weight regulation is not well understood, but we have found that insulin levels seem to correlate primarily with insulin resistance, i.e. abdominal fat $[85,86]$, while plasma leptin correlates better with total fat mass [86]. Therefore, other peripheral signals (i.e. cortisol) are likely to be involved when body weight stabilizes in individual subjects. Furthermore, the likelihood of diabetes appears to be related more to insulin resistance and intra-abdominal fat than total fat mass per se [84]. One consequence of the development of insulin resistance during an increase in adipose mass, therefore, would be to increase plasma insulin levels, and potentially create a stronger satiety signal to the brain to limit further weight gain. This concept conflicts with the proposal that insulin resistance and hyperinsulinaemia are primary causes for the development of obesity and it has important implications for understanding the relationship between obesity, and Type II diabetes. 
In one of the variants of the "thrifty genotype" hypothesis originally proposed by Neel [87], insulin hypersecretion and insulin resistance were perceived as conferring a survival advantage during early human evolution by increasing the efficiency of fat storage. This hypothesized survival benefit of efficient calorie storage in a population of austere hunter-gatherers was proposed to be maladaptive in a modern society where food shortages no longer are prevalent. The consequence is progressive obesity that eventually causes Type II diabetes. This sequence of events was suggested to account for the high prevalence of obesity and diabetes in the Pima Indians of Southwestern Arizona.

However, two recent studies conducted on Pima Indians do not support this hypothesis. In one, it was found that insulin resistance did not predict future weight gain [88]. In contrast, the most insulin-sensitive, non-diabetic members of the population tended to gain the most weight when followed over time. In the second study, reduced insulin secretion in response to intravenous glucose, oral glucose, or to a meal was associated with an increased risk for weight gain in subjects with normal glucose tolerance followed-up for 3.5 years [89]. Thus, increased insulin sensitivity and decreased insulin secretion appeared to be risk factors for weight gain in this population. Considering the effect of CNS insulin to lower food intake, we postulate that any reduction in insulin secretion would contribute to increased food intake because of the reduced satiety. Since this population as a whole is obese and hyperinsulinaemic, the failure of hyperinsulinaemia to prevent obesity suggests that the thrifty genotype confers resistance to CNS insulin action.

In the setting of reduced food availability, the acquisition of CNS insulin resistance might be the factor that confers survival advantage by promoting increased caloric intake and storage. However, according to this model, while affected individuals would be predisposed to obesity upon transition to a modern society, those who secrete relatively large amounts of insulin would be predicted to achieve a steady-state of energy balance sooner than those with relatively reduced insulin secretion. Thus, everyone in the population would be obese and hyperinsulinaemic, but those with impaired insulin secretion would gain more weight, be the most obese, and be predisposed to developing diabetes [5].

This concept of resistance to long-term body weight signals as a mechanism for obesity has received considerable attention recently. Such a mechanism underlies the obesity of the $d b / d b$ mouse and the $f a / f a$ rat, both of which have defects in the leptin receptor as a mechanism for their leptin resistance and obesity [54]. Should minor defects in signalling by CNS adiposity signals be prevalent in a population, this might be an important cause of obesity.
If mild insulin secretory defects were also present, they might be of survival value to a population subsisting on marginal food resources. Such a combination of "defects" could theoretically have been selected for as components of the thrifty genotype. The limited food availability in such primitive conditions would preclude the possibility of great excess in weight in many individuals, thus preventing this relatively mild insulin secretory defect from being expressed as clinical hyperglycaemia or having a selective disadvantage and being eliminated from the population.

We have described a variant in the promoter of the gene encoding beta-cell glucokinase, the high $\mathrm{K}_{\mathrm{m}}$ enzyme that phosphorylates glucose [90]. This promoter variant is associated with a mild impairment in insulin secretion and an increased frequency of impaired glucose tolerance in a population of Japanese-Americans in whom the incidence of diabetes is markedly increased compared with their genetically similar relatives in Japan [91, 92]. This population is also predisposed to central adiposity when consuming a "Western" diet. Impaired insulin secretion and insulin resistance have both been shown to be risk factors for the development of glucose intolerance and intraabdominal fat accumulation in this population. For reasons that are still not clear, this combination of events then predisposes to late beta-cell failure and clinical diabetes mellitus. We have hypothesized that this latter event may be independent and related to the deposition of pancreatic amyloid [93, 94].

Based on this analysis, we hypothesize that reduced CNS responsiveness to adiposity signals is a potential cause of genetic obesity in human populations. When these defects coexist with genetic defects that lead to impaired insulin secretion, affected individuals would be strongly predisposed both to obesity and to the development of Type II diabetes.

\section{Leptin}

The identification of the obese gene $(o b)$ by positional cloning [95] represents a major development in the understanding of body weight regulation. This gene encodes a 146 amino acid protein, termed leptin, which appears to be produced mainly by adipocytes [96]. Defective production of this molecule is the cause of the obesity of the $o b / o b$ mouse, whose entire syndrome of hyperphagia, impaired reproduction, decreased thermogenesis, diabetes, and reduced growth is reversed by treatment with the missing protein. In June 1997, the first human child with a homozygous mutation of the $o b$ gene leading to leptin deficiency was reported [97]. This apparently rare mutation was associated with normal birth weight and progressive obesity, supporting a critical role for leptin in human body adiposity regulation. Leptin circulates at 


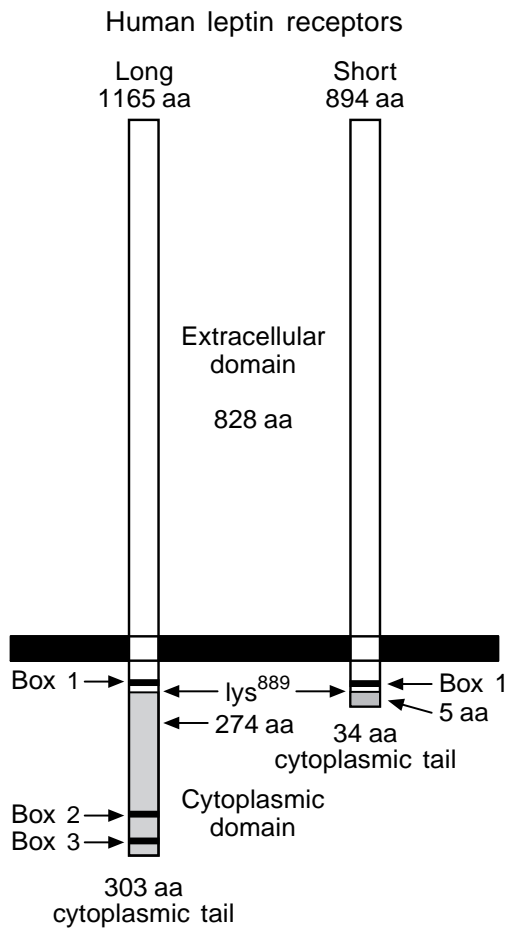

Fig.4. Diagrammatic representation of the two major variants of the leptin receptor. Alternate splicing of the leptin receptor gene produces the full-length "long form" (1165 amino acids) and several different "short forms" that have a truncated cytoplasmic tail. The short form shown here (894 aa) is the predominant form expressed in most tissues except the brain, which expresses mainly the long form. The first C-terminal 889 amino acids of both forms are homologous. Beyond the alternate splice site at lys ${ }^{889}$ in the intracellular domain, the amino acid sequences are non-homologous. The long form has a C-terminal sequence of 274 amino acids containing two consensus sequences (box 2 and box 3 ) for activation of Janus kineses (JAKs) and initiation of downstream signalling via STAT3 proteins, leading to altered gene transcription. The short form lacks box 2 and box 3 but has box 1, which is capable of initiating gene transcription via JAK and STAT5B signalling. In the genetically obese $d b / d b$ mouse, a mutation in the leptin receptor gene produces a premature stop codon in the mRNA transcript at the lys ${ }^{889}$ alternative splice site, resulting in synthesis only of truncated receptor that is identical to the short form. Thus, the absence of the long form receptor in the $d b / d b$ mouse brain results in attenuated leptin signalling, leptin resistance and obesity. The obese Zucker rat $(f a / f a)$ is the result of a mutation leading to a single amino acid substitution $\left(\mathrm{gln}^{269} \rightarrow\right.$ pro $\left.^{269}\right)$ in the extracellular domain and greatly reducing the affinity of the receptor for leptin. The amino acid sequences of human and mouse long form leptin receptors are highly homologous in their extracellular $(78 \%)$ and intracellu$\operatorname{lar}(71 \%)$ domains

concentrations which are directly proportional to body adiposity in animals $[98,99]$ and in man [98, 100-103], and correlates better with total adipose mass than with insulin sensitivity [86, 104], although it is related to both. Circulating leptin levels are higher in females than males even after controlling for adipose mass or percent body fat [104-106], but this difference does not appear to require the continuous presence of oestrogen, since levels are comparable between pre- and post-menopausal women [107]. Leptin is present in CSF at levels that, like insulin, are relatively low (i.e. less than $10 \%$ of the plasma concentration) [108]. The CSF-to-plasma leptin ratio (a measure of CSF uptake efficiency) declines with increasing plasma levels consistent with a saturable uptake mechanism similar to that for insulin.

Leptin binding sites are particularly abundant in the choroid plexus (like insulin binding sites) but are relatively scarce in the hypothalamus $[109,110]$. The leptin receptor gene has been cloned and sequenced and its mRNA is expressed in the choroid plexus, hypothalamus, hippocampus, and in some peripheral tissues [110,111] (Fig. 4). It is a member of the class 1 family of cytokine receptors, without intrinsic tyrosine kinase activity. There are multiple splice variants of the leptin receptor, in which the C-terminal portion of the molecule, contained entirely within the cytoplasm, varies in its length [112]. Early studies demonstrated non-specific expression of receptor mRNA in mouse arcuate NPY neurons [113]. However, the major form expressed in the hypothalamus $[54,114]$ in neurons involved in body weight regulation [115-117] has a 303 amino acid cytoplasmic tail. This "long form" of the receptor is $100 \%$ homologous to several short forms of the receptor, from the N-terminus to an alternate splice site after lys ${ }^{889}$. The major expressed "short form" of the receptor in the choroid plexus and outside the brain has a different 34 amino acid cytoplasmic tail. Janus kinase (JAK) binding sites [118] are present in the C-terminal region of the long form of the receptor and when this form is expressed in vitro in COS cells, activation of the transcription factors STAT-3 and STAT-5 can be demonstrated in response to leptin binding to its receptor $[119,120]$. This has led to the hypothesis that the choroid plexus leptin receptor functions primarily in leptin transport or degradation, although dynamic studies of leptin uptake have not been performed. If the transport system into the CNS is analogous to that for insulin, which is likely based on the very low CSF levels, choroid plexus leptin receptors may be more important for preventing access of leptin to CSF or metabolizing CSF leptin than for mediating its uptake from plasma. We speculate, therefore, that leptin uptake into brain is more likely to occur across the blood-brain barrier endothelium via a receptormediated mechanism similar to that for insulin. Supporting this concept is the report that endothelial leptin receptors were recently identified in blood-brain barrier capillaries isolated from human brain tissue [121], and saturable leptin transport across the blood-brain barrier was recently reported in a rat model [122]. Mutations of the leptin receptor are responsible for the obese phenotype of the $d b / d b$ mouse and the $f a / f a$ rat [54]; the former reflecting 
truncation of the intracellular domain, and the latter due to an extracellular mutation. Both cause defective signalling and leptin resistance [55]. Administration of leptin to $o b / o b$ animals completely reverses the syndrome [123-127], but $d b / d b$ mice and $f a / f a$ rats are insensitive to leptin [125, 126, 128, 129]. In $o b / o b$ the hypothalamic leptin receptor is overexpressed, and this is reversed by leptin treatment [116, 117].

Preliminary screens for mutations or variants of the leptin receptor in human obesity have been unrewarding to date, despite the presence of high levels of circulating leptin in most humans with obesity [98, 100-103]. However, a report suggests an association between a leptin receptor variant, obesity, hyperleptinaemia and increased risk of Type II diabetes in Pima Indians [130]. Assuming that leptin is effective at supraphysiological levels in man, as demonstrated by rodent studies in which exogenous leptin administration reduces food intake, increases UCP-1 in brown fat, and reduces body weight [123-129, 131], it is possible that either reduced leptin signalling or pathologic activation of pathways that oppose leptin (e.g. NPY) may underlie hyperleptinaemia and leptin resistance in many obese humans.

Since leptin-deficient $(o b / o b)$ and resistant $(d b /$ $d b)$ mice and rats $(f a / f a)$ also have high insulin levels [132], it appears that insulin does not compensate for reduced leptin signalling. Consistent with this hypothesis, $f a / f a$ rats fail to suppress food intake or body weight when insulin is infused directly into the brain [61]. Based on the hypothesis that intact leptin signalling is required for CNS responses to insulin, leptin resistance should lead to a condition in which insulin is less effective as a satiety signal. Therefore, it is perhaps not surprising that reducing insulin secretion in animals such as the $d b / d b$ mouse with streptozotocin treatment produces hyperglycaemia, but no further increase in hyperphagia. In fact, this scenario can lead to significant weight loss, if the caloric loss is severe enough, and there is not a compensatory increase of food intake.

Leptin secretion is sensitive to caloric balance as well as the level of fat mass [114]. Therefore, restriction of food intake or starvation leads to a drop in leptin levels greater than predicted for the reduction in adipose mass. While the mechanisms controlling leptin secretion are not completely understood, leptin expression and secretion appear to be under the control, at least partially, of insulin [133]. Therefore, as expected, insulin-deficient diabetes caused marked reductions of adipocyte leptin mRNA and circulating leptin levels which can be restored to normal with insulin treatment. Despite these responses to insulin deficiency and treatment, circulating leptin levels in man do not parallel insulin levels throughout the $24 \mathrm{~h}$ [134]. Rather, plasma leptin levels demonstrate an intrinsic circadian rhythm peaking between mid- night and 03.00 hours, and reaching nadir values between 08.00 and 11.00 hours in the morning. This circadian rhythmicity is dependent on the state of energy balance, since the nocturnal rise in leptin is prevented if food is not consumed during the day. Leptin and insulin, therefore, are afferent circulating signals for the CNS regulation of food intake, energy expenditure, and body weight, with each having the ability to modify the secretion and action of the other.

While defects in insulin secretion are well-documented components of both Type I and Type II diabetes, abnormalities in leptin levels are only evident in untreated insulin deficiency. Plasma leptin levels are correlated with body adiposity among patients with Type II diabetes in a manner that cannot be distinguished from non-diabetic subjects [86, 103]. Moreover, while plasma leptin levels are, like fasting insulin levels, inversely associated with the prevailing level of insulin sensitivity [104], this relationship is dependent on the correlation between body adiposity and leptin levels [86], while fasting insulin levels are correlated with insulin sensitivity independent of body adiposity $[86,135,136]$. Thus, plasma insulin is related to body fat mass via differences in insulin sensitivity, whereas leptin levels are not. These results indicate that plasma insulin and leptin levels are coupled to body adiposity via different mechanisms.

\section{Regulation of individual meal size and its integration with energy balance}

Mechanisms underlying the initiation of meals are not well-understood and meal patterns vary widely from species to species, but all animals eat intermittently. Meal patterns can be easily entrained to environmental cues, such as the time of day or the social situation, making the biological factors that play a role in meal initiation difficult to uncover. In rodents, changes in blood glucose may play a role. There is a small, but statistically significant, drop in plasma glucose just prior to meal initiation [137, 138], and if the spontaneous meal is prevented, plasma glucose levels revert to normal whether or not the animal actually eats. A subsequent meal will not occur immediately, but will be delayed for some period of time until another small spontaneous decline occurs. If similar small declines of glucose are experimentally induced, they lead to spontaneous meal ingestion [139]. This supports the concept that central recognition of the small decline is important to meal initiation. However, the "premeal" decline in plasma glucose can be dissociated from meal initiation by vagotomy, a procedure which produces no long-term effect on body adiposity or food intake [140]. Furthermore, preventing the glucose decline by glucose administration or mild chronic hyperglycaemia does not decrease food intake or change meal patterns in normal subjects 
[68]. This contrasts sharply with the response to more severe hypoglycaemia which is sufficient to activate the sympathetic nervous system. Such hypoglycaemia is a powerful stimulus to eating as an emergency response unrelated to the normal regulation of individual meals or body adiposity [76]. The premeal decrease of glucose has recently been hypothesized to herald an already-initiated eating sequence since the glucose decline is preceded by a small burst of insulin secretion [141, 142].

Once nutrients are ingested, signals are generated which play an important role in the size of the meal by influencing its duration. Neural signals originating in the tongue, the stomach, the duodenum, and the liver are transmitted to the brain and are an important component of this regulatory system. In addition, peptides secreted by the gastrointestinal tract are important contributors to meal termination. It appears that no single satiety signal is critical and that this is a highly redundant system. Stomach stretch receptors play an important role; however, Gibbs and Smith [143] demonstrated that even when stretch is prevented by a gastric fistula, administration of food into the duodenum still terminates a single meal. They found that the duodenal peptide, cholecystokinin (CCK), could replicate this food effect and over a period of 20 years produced a variety of studies that demonstrate the importance of CCK to meal size in rodents, primates, and humans [144-146]. One important site of action for CCK appears to be receptors on vagal afferent fibres in the gastrointestinal tract, especially in the region of the pylorus $[147,148]$. Selective vagal deafferentation markedly attenuates the ability of CCK to reduce meal size [140], although the CCK effect is not lost completely. CCK is also a brain neuropeptide and, when injected into the CNS, suppresses meal size at a dose that is lower than the effective dose systemically $[149,150]$. Thus, there is a central neural system utilizing CCK which produces satiety in addition to the peripheral vagal system which responds to peripheral CCK to regulate meal size.

A number of other peptides also appear to be short-term regulators of meal size. They include glucagon [151], islet amyloid polypeptide or amylin [152], GRP (gastric-releasing peptide in the bombesin family) [153], and enterostatin [154]. Interestingly, each of these is also effective when injected directly into the CNS. Therefore, a family of peptides, some of which are made in the central nervous system in neurons, are also made in the gastrointestinal tract where they bind to receptors on peripheral nerves and produce the same physiologic effect (i.e. suppression of meal size). In the case of CCK, there is substantial evidence that the complete sequence of satiety is induced by the peptide, analogous to that of the ingestion of a meal $[144,155]$. This includes reduced food-seeking behaviour and a tendency to groom and then sleep with a lack of a conditioned taste aversion
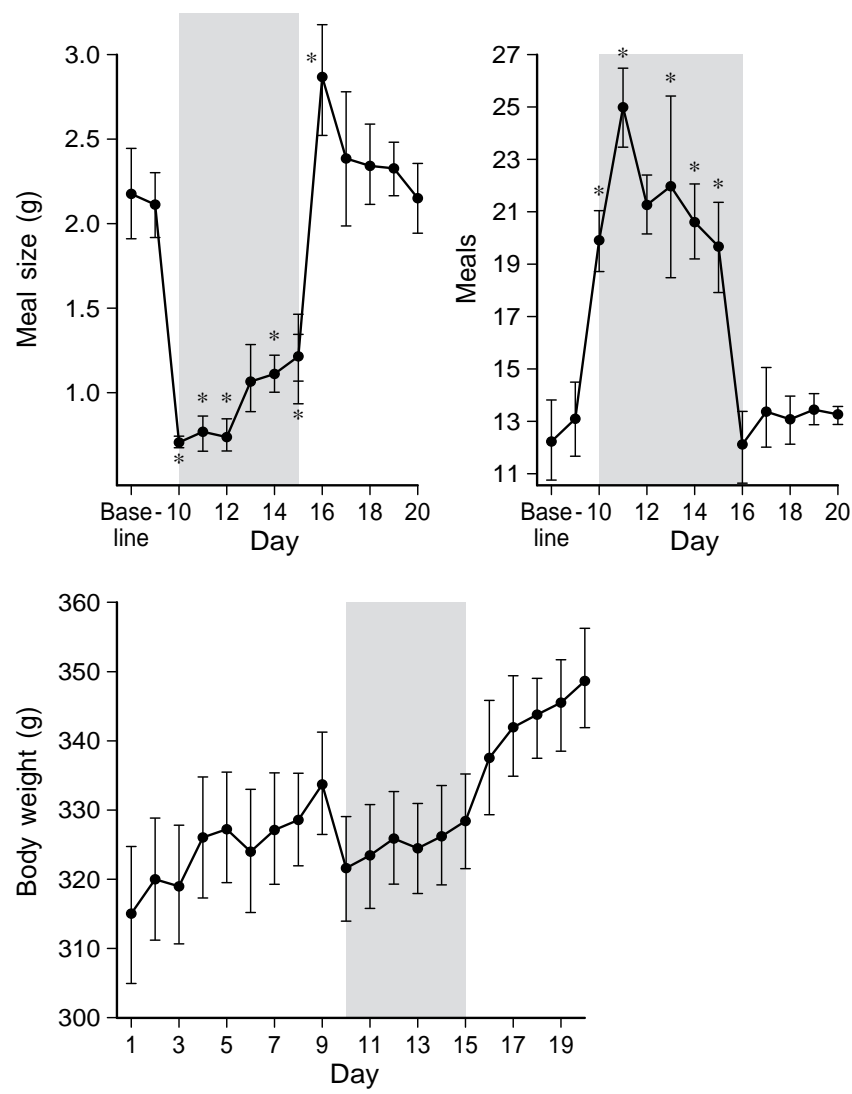

Fig. 5. Effects of repetitive doses of CCK given at the initiation of each meal i. p. in free-feeding rats by a computer-controlled device on daily meal size, meal number, and body weight. Note that despite the effectiveness of CCK to reduce meal size by $50 \%$, meal number doubles to compensate and body weight is only slightly depressed (From ref. 144). Period of CCK administration shaded

(a measure of anorexia produced by noxious stimuli) [156]. Fewer studies have been done with the other putative satiety peptides, but in the case of glucagonlike peptide-1 (GLP-1) there is some evidence that malaise rather than satiety accounts for the effects on food intake, since a conditioned taste aversion results when this peptide is given centrally [157]. Thus, it is possible that anatomically and functionally distinct central neural systems are activated by each of these peptides which have different roles in the maintenance of the body fuel economy.

Despite the efficacy of circulating CCK to reduce single meal size when injected prior to a meal, and the persistence of its effectiveness over time, CCK is not involved in the regulation of body adiposity. This was revealed by intermittent administration of CCK at every spontaneous meal by a computer-controlled system [158]. After a short period of trivial weight loss, meal frequency increased and exactly compensated so that, although smaller meals were eaten, total daily caloric intake returned to control levels, and body weight did not change further (Fig.5). This is 
very different from the effects of leptin or insulin, and emphasizes the fundamental difference between the regulation of single meals and the regulation of body adiposity. Among the satiety peptides that have been tested, most resemble CCK (i.e. there is very little persistent effect on 24-h food intake when administered in a repeated fashion over a period of time).

For insulin and leptin to regulate body weight effectively, however, they are likely to change either meal size or meal frequency. It is our hypothesis that negative CNS feedback signalling in proportion to adipose mass through these molecules ultimately reduces meal size, but via an indirect mechanism. To demonstrate how this might occur, CCK was given either peripherally [159] or centrally $[160,161]$ when insulin was infused continuously ICV at doses below those necessary to lower food intake or body weight. Under these conditions, a subthreshold dose of insulin was able to augment the effect of exogenous CCK to reduce meal size. Similarly, a subthreshold dose of leptin also augmented the effect of CCK to reduce meal size [162]. Thus, the impact of shortterm satiety signals (e.g. CCK) on the size of a single meal is modulated by long-term controllers of body adiposity, insulin, and leptin. Regardless of the caloric value or density of the food consumed, the size of the meal, the quality of the meal, or its macronutrient content (all of which provide variable neural and hormonal responses to the meal from the gastrointestinal tract), it is hypothesized that ultimately these signals will all be modulated by the long-term body weight regulating system. Through this mechanism, meal size can be adjusted in relationship both to individual nutrients and meal patterns and to the state of energy balance.

\section{Brain neurotransmitters in the regulation of body adiposity}

The central neural control systems for the regulation of food intake and energy expenditure are co-ordinated and controlled by neuronal systems converging on the ventral hypothalamus. It has been known for years that lesions in this region produce an increase or a decrease in the regulated weight, depending on the specific site of the lesion [163]. The neural substrate for these responses is complex, since this region is rich in a variety of amines and peptides that influence food intake and energy expenditure. Two nonpeptide systems were the focus of early studies. The catecholamines, norepinephrine, and epinephrine when administered locally into the hypothalamus, have long been known to elicit feeding in satiated animals [164]. This effect has a rapid onset and a short duration, and is largely restricted to the paraventricular region and the VMH [165]. Pharmacological compounds which block $\alpha-2$ adrenergic receptors oppose this effect [166]. In contrast, stimulation of $\alpha-1$ and $\beta-1$ adrenergic receptors in the hypothalamus reduces food intake, and this observation may explain the anorexic effect of sympathomimetic drugs [167]. Depletion of central norepinephrine from neurons supplying $\alpha-2$ receptors may also be part of the mechanism for the anorexic action of amphetamines and related drugs. In contrast, administration of serotonin (5HT) has a suppressive effect on food intake and body weight [168-170]. This effect is particularly potent in the medial hypothalamic areas where endogenous 5-HT has been implicated in the control of food intake. Drugs such as dexfenfluramine, which act by releasing endogenous 5-HT or blocking its reuptake, have been used alone or in combination with amphetamine-like drugs to influence long-term body weight regulation [171].

How or whether these amine systems interact with insulin and/or leptin has not been studied and is not known. It is possible that the limited efficacy of compounds regulating these amine systems for long-term weight reduction reflects the offsetting consequences of falling leptin and/or insulin levels as weight is lost. These amine systems have been associated with preferential intake of specific macronutrients [166], and may be particularly important to the regulation of food selection. However, these monoaminergic systems do not seem to be key participants in normal long-term body adiposity regulation. This conclusion is supported by recent studies of mice lacking norepinephrine [172], in which the consequences for energy homeostasis were quite small.

Several neuropeptides have also been implicated in food intake regulation. However, as with the amines just discussed, many appear to be central effectors of short-term, single-meal control, and are not key effectors that respond to afferent input from long-term body weight regulatory signals. Examples include GLP-1, CCK, the endorphins, bombesin-like peptides, and melanin-concentrating hormone (MCH). GLP-1 [173], CCK [174] and bombesin [175] have been shown to reduce single meal size, but they are not effective in reducing body adiposity when repeatedly administered to the CNS over time. In addition, GLP-1 was recently shown to induce cfos expression (a marker of neuronal activation) $[176,177]$ in the brain in a pattern that is similar to the activation pattern found after administration of lithium chloride, a medication associated with anorexia due to illness, as revealed by formation of a conditioned taste aversion. Despite this, neither GLP-1 nor lithium causes a persistent reduction in body adiposity after repeated administration [157]. Thus, malaise may cause satiety via somewhat different central effector pathways than those involved in energy balance. Similarly, both beta endorphin [178] and $\mathrm{MCH}$ [179] produce short-term increases of meal size. However, neither peptide causes a sustained in- 


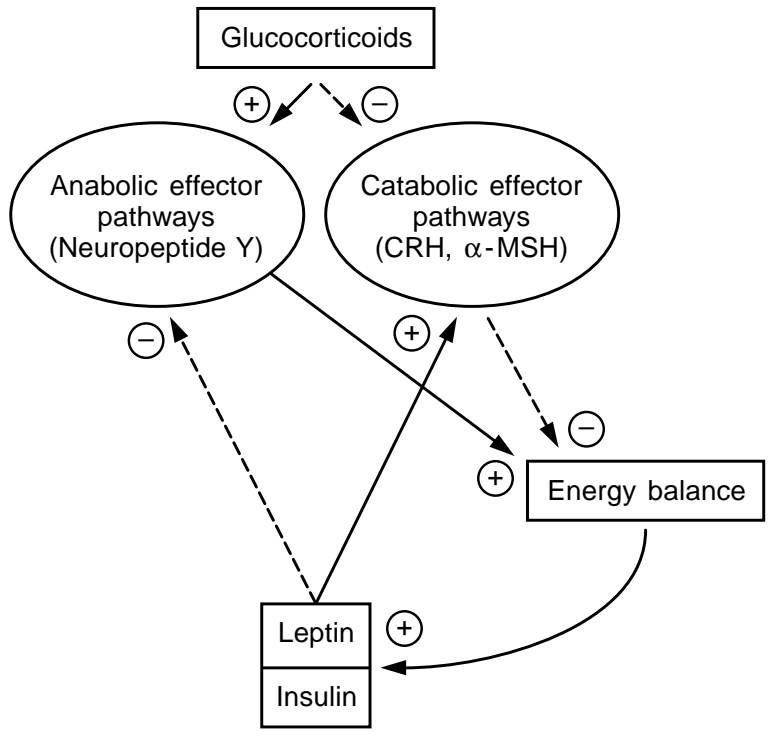

Fig.6. Descriptive physiologic view of the CNS neuronal systems involved in the regulation of energy balance by insulin, leptin, and glucocorticoids

crease of food intake or produces obesity with chronic ICV administration [180]. Furthermore, the physiologic stimuli for endogenous release of these peptides is not known. Therefore, their potential role in the regulation of caloric intake is uncertain and their lack of persistent effects suggest they are not critical participants in long-term body adiposity regulation.

In contrast, three neuropeptides, NPY [181, 182], $\alpha-\mathrm{MSH}$ [183] and CRH [184], are implicated in long-term body weight regulation by the CNS. Hypothalamic pathways containing these neuropeptides interact with and are controlled by the three known long-term afferent signals in the control of body adiposity, insulin, leptin, and adrenal steroids [185] (Fig. 6). While NPY is abundant in the brain and is the primary peptidergic neurotransmitter of the sympathetic nervous system [186] where it is co-localized with norepinephrine, it is also a potent orexigenic compound when administered into the CNS, causing a robust stimulation of food intake in satiated animals. This effect can be demonstrated when NPY is given into the cerebral ventricles [182, 187], but is particularly robust when injected into the paraventricular nucleus $[188,189]$ and adjacent sites [190]. In contrast to the amines and other neuropeptides discussed above, daily micro-injection of NPY into the brain causes a persistent increase in meal size and 24-h food intake and animals experience rapid and marked expansion of adipose stores [182]. In addition, NPY given ICV reduces energy expenditure [191] and stimulates insulin and glucocorticoid secretion [187] that predisposes to the storage of fat.

Although NPY is one of the most abundant neuropeptides of the brain, NPY gene expression in the hypothalamic arcuate nucleus is uniquely sensitive to changes in energy balance [192]. Thus, weight loss due to food restriction is a reliable stimulus for hypothalamic NPY gene transcription, peptide synthesis, and peptide release [193, 194]. Since food restriction also lowers circulating insulin [195] and leptin [196] levels, we hypothesized that hypothalamic NPY production is tonically inhibited by these hormones. Therefore, the relationship between NPY synthesis and release was tested in another state of combined insulin and leptin deficiency, severe streptozotocininduced diabetes in a rat model [74]. Diabetes in the rat increases NPY mRNA and NPY peptide [197, 198], and it can be suppressed in the insulin-deficient animal by peripheral administration of insulin to lower glycaemia [197, 198], or into the CNS without any effect on glycaemia [75]. Similarly NPY is spontaneously overexpressed in the hypothalamus of leptin-deficient $o b / o b$ mice [199], and this response attenuated by the administration of leptin [200-202]. A similar suppression of NPY can be observed in normal rodents [201, 203, 204] in association with an increase in brown fat UCP-1 expression [131].

Despite strong support for the importance of NPY as a central neural effector for the long-term regulation of body adiposity by insulin and leptin, recent studies in an NPY-deficient mouse (NPY "knockout") indicate that this system must be redundant to others [205]. NPY "knockout" mice have nearly normal food intake, body weight, and counterregulatory responses to food deprivation. However, in the $o b /$ $o b$ mouse where leptin is not available, cross-breeding with the NPY "knockout" mouse to produce mice with combined leptin and NPY deficiency leads to a substantial reduction of food intake and body adiposity with improvement in metabolic state and neuroendocrine function [206]. This result demonstrates the critical participation of the NPY system when it has been stimulated by leptin deficiency.

Corticotrophin-releasing hormone $(\mathrm{CRH})$ is known to have a regulatory role in the control of the hypothalamic-pituitary-adrenal axis. However, CRH appears also to function as a catabolic CNS effector molecule involved in the regulation of energy balance $[184,207]$. This CRH effect involves a reciprocal action to reduce food intake while stimulating activity of the sympathetic nervous system. Thus, CRH effects on energy balance also appear to be mediated within the hypothalamic paraventricular nucleus [184, 207-209], and are opposite to those of NPY. Moreover, chronic central CRH administration causes sustained reductions of food intake and body weight in normal rats [210, 211], genetically obese rats [212], rats made obese by lesions in the VMH [213], and rhesus monkeys [214]. As expected, the effect of food deprivation and insulin-deficient diabetes to stimulate food intake are both reversed by insulin treatment [74, 215] and associated with increased NPY, and reduced expression of mRNA for CRH in 
the paraventricular nucleus (PVN) of the rat [74, 216]. Conversely, adrenal insufficiency with its reduced glucocorticoid levels, causes anorexia that is associated with increased $\mathrm{CRH}$ expression in the PVN [28, 208] and reduced expression of NPY [217]. This effect has been reproduced by administration of leptin directly into the brain [127]. Therefore, weight loss induced by adrenal insufficiency likely involves the same body weight regulating system that is controlled by insulin and leptin. This anorectic effect of glucocorticoid deficiency may be viewed as a state of enhanced responsiveness to insulin and leptin; indeed, adrenalectomy potentiates anorexia induced by both hormones $[218,219]$. This observation suggests that negative feedback in the form of insulin and leptin is tonically modulated by the action of glucocorticoids in the CNS $[219,220]$.

The effects of adrenal steroids on food intake and body weight are complex because their administration is associated with hyperinsulinaemia and hyperleptinaemia. Thus, the direct central effect of adrenal steroids to increase NPY mRNA while reducing CRH mRNA may be constrained by opposing indirect peripheral effects of increased steroids on insulin and leptin to regulate these same neuropeptide systems. This concept has been tested by administering variable doses of adrenal steroids to insulin-deficient (and leptin-deficient) streptozotocin-induced diabetic rats [221]. In these animals, glucocorticoids cause a dose-dependent increase in NPY synthesis, and decrease in CRH expression [222], with stimulation of food intake behaviour when insulin levels remain low. This effect is not observed in non-diabetic controls that increase insulin levels in parallel with the level of glucocorticoids. Because hyperphagic refeeding can also be restored in fasted adrenalectomized rats by glucocorticoid administration directly into the brain [223], it appears that the effect of insulindeficiency to stimulate hypothalamic NPY and suppress CRH gene expression and increase food intake is sensitive to direct effects of glucosteroids in the brain. Thus, the ability of adrenalectomy to reverse the hyperphagia and weight gain of experimental obesity in most rodent models [224, 225] may be explained by steroid interaction with the long-term body weight regulating system [226] controlled by leptin and insulin through CNS neural effectors such as NPY and CRH [227].

Another neuropeptide system recently recognized as critical to the regulation of body adiposity is the hypothalamic melanocortin system containing $\alpha$ MSH, a product of the POMC gene expressed by neurons of the arcuate nucleus. A natural antagonist of $\alpha$-MSH melanocortin receptors (known as agouti protein) produces obesity when overexpressed in the central nervous system of $\mathrm{A}^{\mathrm{y}}$ yellow obese mice (the agouti mouse) [183, 228]. One type of predominantly neural melanocortin receptor known to bind $\mathrm{MSH}$, the MC-4 receptor, was "knocked out" [228]. The phenotype of this "knockout" mouse is characterized by persistent hyperphagia and a marked increase in body adiposity. Such a finding suggests that tonic stimulation of the $\alpha \mathrm{MSH} / \mathrm{MC}-4$ receptor system in the brain is necessary to maintain normal body adiposity.

\section{Obesity and Type II diabetes: a shared pathophysiology?}

The complex interactions of the central controllers for long-term body adiposity and their regulation by afferent hormonal signals, are making it clear that the neural substrates upon which carbohydrate metabolism and body weight regulation act overlap with one another. It is this overlap which we believe leads to a tendency for these two disorders to occur together. At their simplest, reduction of insulin and leptin secretion, blood-brain barrier transport, or neuronal responsiveness should lead to an increase in caloric intake and storage. When these two phenomena occur simultaneously, the most obese individual would be the most hyperglycaemic. Thus, it is our general hypothesis that diabetes and obesity, the odd couple, occur together because carbohydrate metabolism and body weight regulation utilize common afferent and central signalling mechanisms.

The mutual interdependence of physiological systems responsible for stability of blood glucose and of body adiposity is perhaps best demonstrated by the consequences of insulin deficiency. In peripheral tissues, severe insulin deficiency leads to unrestrained hepatic glucose production and impaired insulin stimulated glucose uptake and consequently, to marked hyperglycaemia. When circulating glucose levels exceed the renal threshold, glycosuria ensues, and ingested calories are lost from the body. The effect of insulin deficiency to reduce lipoprotein lipase activity [229-231] and to activate hormone-sensitive lipase in adipose tissue leads to unrestrained hydrolysis of adipocyte triglyceride, the inability to store ingested calories as fat, and the consequent depletion of fat stores. Leptin synthesis and secretion also decline sharply, causing systemic leptin deficiency. This combination of insulin and leptin deficiency is detected by the brain as characteristic of starvation, and the hypothalamus responds with increased NPY signalling and decreased $\mathrm{CRH}$ signalling. Consequently, food intake increases while sympathetic activation of brown adipose tissue decreases, in a futile effort to restore positive energy balance. Thus, the deficiency of a single hormone, insulin, leads to disturbances in the homeostasis of both the blood glucose level and fat stores.

Animals suffering from severe leptin deficiency or leptin resistance experience a different disturbance of energy balance and glucose homeostasis, charac- 
terized by unrestrained activation of anabolic signalling systems in the hypothalamus in the presence of marked hyperinsulinaemia [132]. This observation led to the hypothesis that insulin action in the hypothalamus is ineffective in the absence of leptin signalling. Consistent with this hypothesis, the obese, $f a / f a$ Zucker rat reduces neither food intake [61] nor hypothalamic NPY gene expression in response to ICV insulin administration [232]. This finding directly supports the conclusion that insulin action in the hypothalamus requires leptin signalling since obesity in these animals results from a mutation in the leptin receptor $[54,55]$. The combination of impaired signalling from both leptin and insulin leads to hypothalamic responses similar to those in uncontrolled diabetes, e.g. unrestrained activation of CNS anabolic effector systems and hyperphagia. In contrast to the insulin-deficient diabetic animal, however, circulating insulin is very high and readily promotes fat storage. Extreme obesity is therefore the ultimate outcome. Since NPY acting in the hypothalamus reduces insulin sensitivity in skeletal muscle [233], unrestrained activation of the NPY system in this setting also exacerbates systemic insulin resistance and hyperinsulinaemia. As obesity progresses, insulin resistance becomes more severe, and carbohydrate intolerance ensues despite markedly elevated circulating insulin levels. Thus, like insulin deficiency diabetes, defective leptin signalling in the $f a / f a$ rat results in a severe phenotype characterized by hyperphagia and obesity with mild hyperglycaemia.

Critical evidence in support of this sequence was provided by Erickson and colleagues [206] who demonstrated that both the obesity syndrome and the disturbance of glucose homeostasis of $o b / o b$ mice are attenuated by genetic deficiency of NPY. Therefore, the consequence of leptin deficiency to cause both carbohydrate intolerance and excessive fat storage, appears to be dependent in part on NPY signalling within the brain which has become insensitive to insulin. In other words, leptin production by the adipocyte is critically dependent on insulin and insulin action in the brain is critically dependent on leptin.

This interdependence of signalling systems takes on greater importance when one considers the hypothetical example of an individual with a less severe defect in CNS leptin signalling. Such an individual with a $50 \%$ reduction in the CNS response to the circulating leptin signal could have a defect at the level of leptin transport into the CNS, expression of leptin receptors, neuronal production of second messengers in response to leptin binding, or the ability to activate downstream mediators. In this setting, one predicts that a steady-state of energy balance would require twice the normal levels of leptin. Moreover, the hypothesis that $\mathrm{CNS}$ insulin signalling requires leptin signalling suggests that an increase in circulating insulin levels may also be required for normal CNS insu-

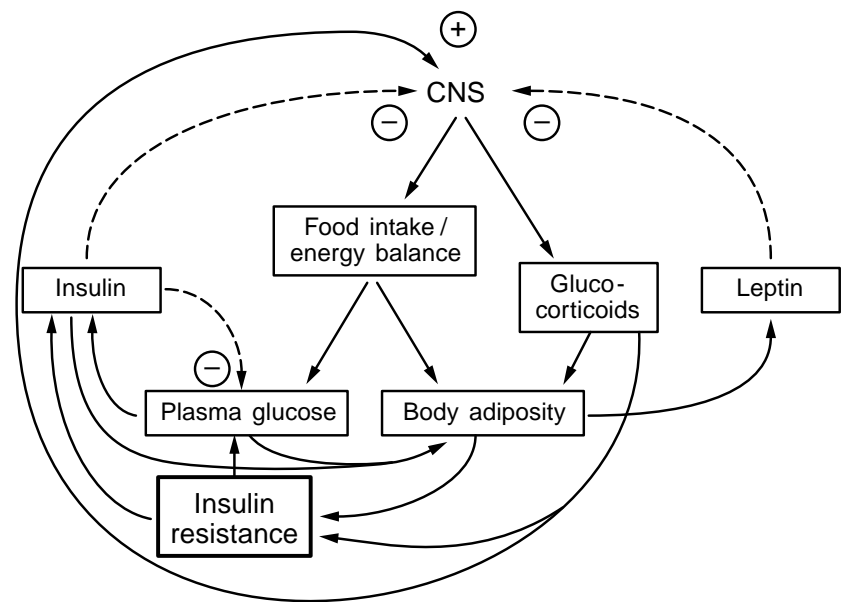

Fig. 7. Proposed model of the interaction between the energy balance and plasma glucose regulating systems

lin responses. Such an individual should have increased signalling mediated by hypothalamic anabolic pathways, which increases food intake, promotes obesity, and causes systemic insulin resistance. If an individual also has a genetic defect in insulin secretion such as the glucokinase promoter variant, glucose tolerance may deteriorate progressively as weight gain increases. Therefore, this model predicts that a single, incomplete lesion in CNS leptin signalling would predispose a person to obesity, insulin resistance, and glucose intolerance, despite hyperinsulinaemia. If one has an additional genetic disturbance that limits the ability to mount an appropriate hyperinsulinaemic response, a progressive hyperglycaemia and further weight gain will occur if the insulin signalling defect is mild. The degree of obesity and hyperglycaemia would depend on the relative severity of these two defects.

This model of a common pathogenesis of obesity and Type II diabetes is intended to provide insight into how relatively simple defects in two complex regulatory systems which share signalling molecules can cause progressive disturbances of both energy balance and glucose metabolism in man (Fig. 7). By now recognizing that both diabetes and obesity, previously considered peripheral metabolic disorders, involve dysfunction of the central nervous system, we anticipate further progress in our understanding of the pathogenesis of these common diseases of regulation. From this knowledge, it is hoped that improved treatment of both disorders will emerge.

Acknowledgements. This work was supported by the Department of Veteran Affairs as well as NIH grants DK 12829, DK 17047, DK 17844, NS 32273, and DK 40963. 


\section{References}

1. Bierman EL, Bagdade JD, Porte D, Jr. (1968) Obesity and diabetes: The odd couple. J Clin Nutr 21: 1434-1437

2. Kahn SE, Porte D, Jr. (1996) Pathophysiology of type II (noninsulin-dependent) diabetes mellitus: implications for treatment. In: Porte D, Jr., Sherwin RS (eds) Diabetes mellitus, theory and practice. Appleton and Lange, New York, pp 487-512

3. Schwartz MW, Figlewicz DP, Baskin DG et al. (1992) Insulin in the brain: a hormonal regulator of energy balance. Endocr Rev 13: 387-414

4. Schwartz MW, Figlewicz DP, Baskin DG et al. (1994) Insulin and the central regulation of energy balance: Update 1994. Endocr Rev Monographs 2: 109-113

5. Kaiyala KJ, Woods SC, Schwartz MW (1995) A new model for the regulation of energy balance by the central nervous system. Am J Clin Nutr 62 [Suppl]: 1123S-1134S

6. Kennedy GC (1953) The role of depot fat in the hypothalamic control of food intake in the rat. Proc R Soc Lond (Lond) 140: 579-592

7. Klaus S, Casteilla L, Bouillaud F et al. (1991) The uncoupling protein UCP: a membranous mitochondrial ion carrier exclusively expressed in brown adipose tissue. Int $\mathrm{J}$ Biochem 23: 791-801

8. Lowell BB, Flier JS (1997) Brown adipose tissue, beta 3adrenergic receptors, and obesity. Annu Rev Med 48: 307-316

9. Fleury C, Neverova M, Collins S et al. (1997) Uncoupling protein-2: a novel gene linked to obesity and hyperinsulinemia. Nat Genet 15: 269-272

10. Vidal-Puig A, Solanes G, Grujic D et al. (1997) UCP3: an uncoupling protein homologue expressed preferentially and abundantly in skeletal muscle and brown adipose tissue. Biochem Biophys Res Commun 235: 79-82

11. Boss O, Samec S, Paoloni-Giacobino A et al. (1997) Uncoupling protein-3: a new member of the mitochondrial carrier family with tissue-specific expression. FEBS Lett 408: 39-42

12. Luiten PGM, Ter Horst GJ, Steffens AB (1987) The hypothalamus, intrinsic connections and outflow pathways to the endocrine system in relation to the control of feeding and metabolism. Prog Neurobiol 28: 1-54

13. Schwartz GJ, Moran TH (1996) Sub-diaphragmatic vagal afferent integration of meal-related gastrointestinal signals. Neurosci Biobehav Rev 20: 47-56

14. Woods SC, West DB, Stein LJ et al. (1981) Peptides and the control of meal size. Diabetologia 20: 305-313

15. Keesey RE, Powley TL (1986) The regulation of body weight. Ann Rev Psychol 37: 109-133

16. Stallone DD, Stunkard AJ (1991) The regulation of body weight: evidence and clinical implications. Ann Behav Med 13: 220-230

17. Edholm OG (1977) Energy balance in man studies carried out by the Division of Human Physiology, National Institute for Medical Research. J Hum Nutr 31: 413-431

18. Kieffer TJ, Heller RS, Leech CA et al. (1997) Leptin suppression of insulin secretion by the activation of ATP-sensitive $\mathrm{K}+$ channels in pancreatic B-cells. Diabetes 46: 1087-1093

19. Koyama K, Chen GX, Wang MY et al. (1997) Beta-cell function in normal rats made chronically hyperleptinemic by adenovirus-leptin gene therapy. Diabetes 46: 1276-1280

20. Safer DJ (1991) Diet, behavior modification, and exercise: a review of obesity treatments from a long-term perspective. Southern Med J 84: 1470-1474
21. Garner DM, Wooley SC (1991) Confronting the failure of behavorial and dietary treatments for obesity. Clin Psych Rev 11 (6): 729-780

22. Drenick EJ, Johnson D (1978) Weight reduction by fasting and semistarvation in morbid obesity: long-term follow-up. Int J Obesity 2: 123-132

23. Keesey RE, Corbett SW (1984) Metabolic defense of the body weight set-point. Raven Press, New York, pp 87-96

24. Mayer J, Thomas DW (1967) Regulation of food intake and obesity. Science 156 (773): 328-337

25. Bernstein IL, Lotter EC, Kulkosky PJ (1975) Effect of force-feeding upon basal insulin levels in rats. Proc Soc Exp Biol Med 150: 546-548

26. Faust IM, Johnson PR, Hirsch J (1977) Adipose tissue regeneration following lipectomy. Science 197: 391-393

27. Larson KA, Anderson DB (1978) The effects of lipectomy on remaining adipose tissue depots in the Sprague Dawley rat. Growth 42: 469-477

28. Bray GA, Fisler J, York DA (1990) Neuroendocrine control of the development of obesity: understanding gained from studies of experimental animal models. Front Neuroendocrinol 11: 128-181

29. Bagdade JD, Bierman EL, Porte D, Jr. (1967) The significance of basal insulin levels in the evaluation of the insulin response to glucose in diabetic and nondiabetic subjects. J Clin Invest 46: 1549-1557

30. Baskin DG, Figlewicz DP, Woods SC et al. (1987) Insulin in the brain. Ann Rev Physiol 49: 335-347

31. Hopkins DF, Williams G (1997) Insulin receptors are widely distributed in human brain and bind human and porcine insulin with equal affinity. Diabet Med 14: 1044-1050

32. Woods SC, Porte D, Jr. (1978) Relationship between plasma and cerebrospinal fluid insulin level of dogs. Am J Physiol 233: 331-334

33. Wallum BJ, Taborsky GJ, Jr., Porte D, Jr. et al. (1987) Cerebrospinal fluid insulin levels increase during intravenous insulin infusions in man. J Clin Endocrinol Metab 64: 190-194

34. Shapiro E, Brown SD, Saltiel AR et al. (1991) Short-term action of insulin on Aplysia neurons: generation of a possible novel modulator of ion channels. J Neurobiol 22: $55-62$

35. Figlewicz DP, Szot P, Chavez M et al. (1994) Intraventricular insulin increases dopamine transporter mRNA in rat ventral tegmental area/substantia nigra. Brain Res 644: 331-334

36. Masters BA, Shemer J, Judkins JH et al. (1987) Insulin receptors and insulin action in dissociated brain cells. Brain Res 417: 247-256

37. Oliver EH, Sartin JL, Dieberg G et al. (1989) Effects of acute insulin deficiency on catecholamine and indoleamine content and catecholamine turnover in microdissected hypothalamic nuclei in streptozotocin-diabetic rats. Acta Endocrinol (Copenh) 120: 343-350

38. Peinado JM, Meyers RD (1991) Norepinephrine release from PVN and lateral hypothalamus during perfusion with 2-DG or insulin in the sated and fasted rat. Pharm Biochem Behav 27: 715-721

39. Figlewicz DP, Szot P, Israel PA et al. (1993) Insulin reduces norepinephrine transporter mRNA in vivo in rat locus coeruleus. Brain Res 602: 161-164

40. Bothwell M (1982) Insulin and somatomedin MSA promote nerve growth factor-independent neurite formation by cultured chick dorsal root ganglionic sensory neurons. J Neurosci Res 8: 225-231 
41. Knusel B, Michel PP, Schwaber JS et al. (1990) Selective and nonselective stimulation of central cholinergic and dopaminergic development in vitro by nerve growth factor, basic fibroblast growth factor, epidermal growth factor, insulin and the insulin-like growth factors I and II. J Neurosci 10: 557-570

42. Adamo M, Raizada MK, LeRoith D (1989) Insulin and insulin-like growth factor receptors in the nervous system. Mol Neurobiol 3: 71-100

43. Baskin DG, Sipols AJ, Schwartz MW et al. (1994) Insulin receptor substrate-1 (IRS-1) expression in rat brain. Endocrinology 134: 1952-1955

44. Schwartz MW, Bergman RN, Kahn SE et al. (1991) Evidence for uptake of plasma insulin into cerebrospinal fluid through an intermediate compartment in dogs. J Clin Invest 88: 1272-1281

45. Steffens AB, Scheurink AJ, Porte D, Jr. et al. (1988) Penetration of peripheral glucose and insulin into cerebrospinal fluid in the rat. Am J Physiol 255: R200-R204

46. Pardrige WM (1986) Receptor-mediated peptide transport through the blood-brain barrier. Endocr Rev 7: 314-330

47. Schwartz MW, Sipols AJ, Kahn SE et al. (1990) Kinetics and specificity of insulin uptake from plasma into cerebrospinal fluid. Am J Physiol 259: E378-E383

48. Baura G, Foster D, Porte D, Jr. et al. (1993) Saturable transport of insulin from plasma into the central nervous system of dogs in vivo: a mechanism for regulated insulin delivery to the brain. J Clin Invest 92: 1824-1830

49. Wood JH (1980) Physiology, pharmacology and dynamics of cerebrospinal fluid. In: Wood J (ed) Neurobiology of cerebrospinal fluid. Plenum Publishing, New York, pp 1-16

50. Baskin DG, Brewitt DA, Davidson DA et al. (1986) Quantitative autoradiographic evidence for insulin receptors in the choroid plexus of the rat brain. Diabetes 35: 246-249

51. Manin M, Broer Y, Balage M et al. (1990) Metabolic clearance of insulin from the cerebrospinal fluid in the anesthetized rat. Peptides 11: 5-12

52. Baura G, Foster DM, Kaiyala K et al. (1996) Insulin transport from plasma into the central nervous system is inhibited by dexamethasone in dogs. Diabetes 45: 86-90

53. Stein LJ, Dorsa DM, Baskin DG et al. (1987) Reduced effect of experimental peripheral hyperinsulinemia to elevate cerebrospinal fluid insulin concentrations of obese Zucker rats. Endocrinology 121: 1611-1615

54. Chua SC, Chung WK, Wu-Peng XS et al. (1996) Phenotypes of mouse diabetes and rat fatty due to mutations in the OB (leptin) receptor. Science 271: 994-996

55. Chua SC, White DW, Wupeng XS et al. (1996) Phenotype of fatty due to Gln269Pro mutation in the leptin receptor (Lepr). Diabetes 45: 1141-1143

56. Schwartz MW, Figlewicz DP, Kahn SE et al. (1990) Insulin binding to brain capillaries is reduced in genetically obese hyperinsulinemic Zucker rats. Peptides 11: 467-472

57. Jialal I, King GL, Buchwald S et al. (1984) Processing of insulin by bovine endothelial cells in culture: internalization without degradation. Diabetes 33: 794-800

58. King GL, Johnson SM (1985) Receptor-mediated transport of insulin across endothelial cells. Science 227: 1583-1586

59. Pardridge WM, Kang YS, Buciak JL et al. (1995) Human insulin receptor monoclonal antibody undergoes high affinity binding to human brain capillaries in vitro and rapid transcytosis through the blood-brain barrier in vivo in the primate. Pharm Res 12: 807-816
60. Van Houten M, Posner BI, Kopriwa BM et al. (1980) Insulin binding sites localized to nerve terminals in rat median eminence and arcuate nucleus. Science 207: 1081-1083

61. Ikeda H, West DB, Pustek JJ et al. (1986) Intraventricular insulin reduces food intake and body weight of lean but not obese Zucker rats. Appetite 7: 381-386

62. Plata-Salaman CR, Oomura Y (1986) Effect of intra-third ventricular administration of insulin on food intake after food deprivation. Physiol Behav 37: 735-739

63. Plata-Salaman CR, Oomura Y, Shimizu N (1986) Dependence of food intake on acute and chronic ventricular administration of insulin. Physiol Behav 37: 717-734

64. Foster LA, Ames NK, Emery RS (1991) Food intake and serum insulin responses to intraventricular infusions of insulin and IGF-I. Physiol Behav 50 (4): 745-749

65. Florant GL, Singer L, Scheurink AJ et al. (1991) Intraventricular insulin reduces food intake and body weight of marmots during the summer feeding period. Physiol Behav 49: 335-338

66. Woods SC, Stein LJ, McKay LD et al. (1979) Chronic intracerebroventricular infusion of insulin reduces food intake and body weight of baboons. Nature 282: 503-505

67. Vanderweele DA, Haraczkiewicz E, Van Itallie TB (1982) Elevated insulin and satiety in obese and normal weight rats. Appetite 3: 99-109

68. Woods SC, Stein LJ, McKay LD et al. (1984) Suppression of food intake by intravenous nutrients and insulin in the baboon. Am J Physiol 247: R393-R401

69. Chavez M, Seeley RJ, Woods SC (1995) A comparison between the effects of intraventricular insulin and intraperitoneal $\mathrm{LiCl}$ on three measures sensitive to emetic agents. Behav Neurosci 109: 547-550

70. Chavez M, Kaiyala K, Madden LJ et al. (1995) Intraventricular insulin and the level of maintained body weight in rats. Behav Neurosci 109: 528-531

71. Rothwell NJ, Saville ME, Stock MJ (1983) Role of insulin in thermogenic responses to refeeding in 3-day-fasted rats. Am J Physiol 245: E160-E165

72. Rothwell NJ, Stock MJ (1984) The development of obesity in animals: the role of dietary factors. Clin Endocrinol Metab 13: 437-449

73. Kaiyala KJ, Woods SC, Schwartz MW (1996) Circulating insulin and its transport into the brain before and during high fat feeding in dogs. J Invest Med 44: 159A (Abstract)

74. Sipols AJ, Baskin DG, Schwartz MW (1995) Effect of intracerebroventricular insulin infusion on diabetic hyperphagia and hypothalamic neuropeptide gene expression. Diabetes 44: 147-151

75. The DCCT Study Group (1988) Weight gain associated with intensive therapy in the Diabetes Control and Complications Trial. Diabetes Care 11: 567-573

76. Woods SC, Porte DJ (1978) The central nervous system, pancreatic hormones, feeding and obesity. Adv Metab Dis 9: 283-312

77. Vague J (1996) Sexual differentiation. A determinant factor of the forms of obesity 1947 (classical article). Obes Res 4: 201-203

78. Vague J, Vague P, Tramoni M et al. (1980) Obesity and diabetes. Acta Diabetol Lat 17: 87-99

79. Bjorntorp P (1990) Classification of obese patients and complications related to the distribution of surplus fat. Nutrition 6: 131-137

80. Bjorntorp P (1997) Body fat distribution, insulin resistance, and metabolic diseases. Nutrition 13: 795-803

81. Bouchard C (1997) Genetic determinants of regional fat distribution. Hum Reprod 12: 1-5 
82. Rice T, Despres JP, Daw EW et al. (1997) Familial resemblance for abdominal visceral fat: the HERITAGE family study. Int J Obes Relat Metab Disord 21: 1024-1031

83. Chagnon YC, Perusse L, Bouchard C (1998) The human obesity gene map: The 1997 update. Obesity Res 6: 76-92

84. Bjorntorp P (1997) Obesity and diabetes mellitus. In: Porte D, Jr., Sherwin RS (eds) Diabetes mellitus, theory and practice. Appleton \& Lange, Stamford, pp 553-564

85. Kahn SE, Prigeon RL, McCulloch DK et al. (1993) Quantification of the relationship between insulin sensitivity and b-cell function in human subjects. Evidence for a hyperbolic function. Diabetes 42: 1663-1672

86. Schwartz MW, Prigeon RL, Kahn SE et al. (1997) Evidence that plasma leptin and insulin levels are associated with body adiposity via different mechanisms. Diabetes Care 20: 1476-1481

87. Neel JV (1962) Diabetes mellitus: a "thrifty" genotype rendered detrimental by "progress"? Am J Hum Genet 14: 353-362

88. Swinburn BA, Nyomba BL, Saad MF et al. (1991) Insulin resistance associated with lower rates of weight gain in Pima Indians. J Clin Invest 88: 168-173

89. Schwartz M, Boyko E, Kahn S et al. (1995) Reduced insulin secretion: an independent predictor of body weight gain. J Clin Endocrinol Metab 80: 1571-1576

90. Stone LM, Kahn SE, Deeb SS et al. (1996) A variation at position -30 of the B-cell glucokinase gene promoter is associated with reduced B-cell function in middle-aged Japanese-American men. Diabetes 45: 422-428

91. Fujimoto WY, Abbata SL, Kahn SE et al. (1994) The visceral adiposity syndrome in Japanese-American men. Obesity Res 2: 364-371

92. Fujimoto WY, Bergstrom RW, Boyko EJ et al. (1994) Diabetes and diabetes risk factors in second- and third-generation Japanese Americans in Seattle, Washington. Diabetes Res Clin Pract 24: S43-S52

93. Porte D, Jr. (1996) Normal physiology and phenotypic characterization of beta cell function in subjects at risk for type 2 diabetes mellitus. Diabet Med 13: S25-S32

94. Porte D, Jr., Kahn SE (1989) Perspectives in diabetes. Hyperproinsulinemia and amyloid in type II diabetes: clues to the etiology of islet B-cell dysfunction? Diabetes 38: 1333-1336

95. Zhang Y, Proenca R, Maffei M et al. (1994) Positional cloning of the mouse obese gene and its human homologue. Nature 372: 425-432

96. Masuzaki H, Ogawa Y, Isse N et al. (1995) Human obese gene expression. Adipocyte-specific expression and regional differences in the adipose tissue. Diabetes 44: 855-858

97. Montague CT, Farooqi IS, Whitehead JP et al. (1997) Congenital leptin deficiency is associated with severe early-onset obesity in humans. Nature 387: 903-908

98. Maffei M, Halaas J, Ravussin E et al. (1995) Leptin levels in human and rodent: measurement of plasma leptin and ob RNA in obese and weight-reduced subjects. Nature Medicine 1: 1155-1161

99. Frederich RC, Hamann A, Anderson S et al. (1995) Leptin levels reflect body lipid content in mice: evidence for diet-induced resistance to leptin action. Nature Medicine 1: $1311-1314$

100. Considine RV, Sinha MK, Heiman ML et al. (1996) Serum immunoreactive-leptin concentrations in normal-weight and obese humans. New Eng J Med 334: 292-295

101. Considine RV, Considine EL, Williams CJ et al. (1995) Evidence against either a premature stop condon or the absence of obese gene mRNA in human obesity. J Clin Invest 96: $2720-2728$
102. Lonnqvist F, Arner P, Nordfors L et al. (1995) Overexpression of the obese (ob) gene in adipost tissue of human obese subjects. Nature Medicine 1: 950-953

103. McGregor GP, Desaga JF, Ehlenz K et al. (1996) Radioimmunological measurement of leptin in plasma of obese and diabetic human subjects. Endocrinology 137: 1501-1504

104. Larsson H, Elmstahl S, Ahren B (1996) Plasma leptin levels correlate to islet function independently of body fat in postmenopausal women. Diabetes 45: 1580-1584

105. Havel P, Kasim-Karakas S, Mueller W et al. (1996) Relationship of plasma leptin to plasma insulin and adiposity in normal weight and overweight women: effects of dietary fat content and sustained weight loss. J Clin Endocrinol Metab 81: 4406-4413

106. Rosenbaum M, Nicolson M, Hirsch J et al. (1996) Effects of gender, body composition, and menopause on plasma concentrations of leptin. J Clin Endocrinol Metab 81 (9): 3424-3427

107. Havel P, Kasim-Karakas S, Dubuc GR et al. (1996) Gender differences in plasma leptin concentrations (letter). Nat Med 2 (9): 949-950

108. Schwartz MW, Peskind E, Raskind M et al. (1996) Cerebrospinal fluid leptin levels: Relationship to plasma levels and to adiposity in humans. Nature Medicine 2: 589-593

109. Malik KF, Young WSI (1996) Localization of binding sites in the central nervous system for leptin (OB protein) in normal, obese (ob/ob), and diabetic (db/db) C57BL/6J mice. Endocrinology 137: 1497-1500

110. Tartaglia LA (1997) The leptin receptor. J Biol Chem 272: 6093-6096

111. Tartaglia LA, Dembski M, Weng X et al. (1995) Identification and expression cloning of a leptin receptor, OB-R. Cell 83: 1263-1271

112. Lee G, Proenca R, Montez JM et al. (1996) Abnormal splicing of the leptin receptor in diabetic mice. Nature 379: 632-635

113. Mercer JG, Hoggard N, Williams LM et al. (1996) Coexpression of leptin receptor and preproneuropeptide $\mathrm{Y}$ mRNA in arcuate nucleus of mouse hypothalamus. J Neuroendocrinol 8: 733-735

114. Kolaczynski J, Considine R, Ohannesian J et al. (1996) Responses of leptin to short-term fasting and refeeding in humans. Diabetes 45: 1511-1515

115. Baskin DG, Kochan JP, Campfield LA et al. (1997) Localization of the leptin receptor long form protein and mRNA in the rat hypothalamus. Endo Soc Abstr: 95

116. Baskin DG, Seeley RJ, Kuijper JL et al. (1998) Increased expression of mRNA for the long form of the leptin receptor $(\mathrm{OB}-\mathrm{Rb})$ in the hypothalamus is associated with leptin hypersensitivity and fasting. Diabetes 47: 538543

117. Mercer JG, Hoggard N, Williams L et al. (1996) Localization of leptin receptor mRNA and the long form splice variant $(\mathrm{Ob}-\mathrm{Rb})$ in mouse hypothalamus and adjacent brain regions by in situ hybridization. FEBS Lett 387: $113-116$

118. Ihle JN (1995) Cytokine receptor signaling. Nature 377: 591-594

119. Ghilardi N, Ziegler S, Wiestner A et al. (1996) Defective STAT signaling by the leptin receptor in diabetic mice. Proc Natl Acad Sci 93: 6231-6235

120. White D, Kuropatwinski K, Devos R et al. (1997) Leptin receptor (OB-R) signaling. J Biol Chem 272 (7): 4065-4071

121. Golden PL, Maccagnan TJ, Pardrige WM (1997) Human blood-brain barrier leptin receptor. Binding and endocy- 
tosis in isolated human brain microvessels. J Clin Invest 99: $14-18$

122. Banks WA, Kastin AJ, Huang W et al. (1996) Leptin enters the brain by a saturable system independent of insulin. Peptides 17: 305-311

123. Weigle DS, Bukowski TR, Foster DC et al. (1995) Recombinant ob protein reduces feeding and body weight in the ob/ob mouse. J Clin Invest 96: 2065-2070

124. Pelleymounter MA, Cullen MJ, Baker MB et al. (1995) Effects of the obese gene product on body weight regulation in ob/ob mice. Science 269: 540-543

125. Halaas JL, Gajiwala KS, Maffei M et al. (1995) Weight-reducing effects of the plasma protein encoded by the obese gene. Science 269: 543-546

126. Campfield L, Smith F, Gulsez Y et al. (1995) Mouse OB protein: evidence for a peripheral signal linking adiposity and central neural networks. Science 269: 546-549

127. Schwartz MW, Seeley RJ, Campfield LA et al. (1996) Identification of targets of leptin action in rat hypothalamus. J Clin Invest 98: 1101-1106

128. Seeley RJ, van Dijk G, Campfield LA et al. (1997) Intraventricular leptin reduces food intake and body weight of lean rats but not Zucker obese rats. Horm Metab Res 28: 664-668

129. Cusin I, Rohner-Jeanrenaud F, Stricker-Krongrad A et al. (1996) The weight-reducing effect of an intracerebroventricular bolus injection of leptin in genetically obese fa/fa rats. Diabetes 45: 1446-1450

130. Thompson DB, Ravussin E, Bennett PH et al. (1997) Structure and sequence variation at the human leptin receptor gene in lean and obese Pima Indians. Hum Mol Genet 6: 675-679

131. Wang Q, Bing C, Al-Barazanji K et al. (1997) Interactions between leptin and hypothalamic neuropeptide $\mathrm{Y}$ neurons in the control of food intake and energy homeostasis in the rat. Diabetes 46: 335-341

132. Coleman DL (1978) Obese and diabetes: two mutant genes causing diabetes-obesity syndromes in mice. Diabetologia 14: 141-148

133. Kolaczynski JW, Nyce MR, Considine RV et al. (1996) Acute and chronic effect of insulin on leptin production in humans. Diabetes 45: 699-701

134. Sinha MK, Ohannesian JP, Heiman ML et al. (1996) Nocturnal rise of leptin in lean, obese, and non-insulin-dependent diabetes mellitus subjects. J Clin Invest 97: 1344-1347

135. Larsson H, Ahren B (1996) Failure to adequately adapt reduced insulin sensitivity with increased insulin secretion in women with impaired glucose tolerance. Diabetologia 39: 1099-1107

136. Bergman RN, Phillips LS, Cobelli C (1981) Physiologic evaluation of factors controlling glucose tolerance in man: measurement of insulin sensitivity and beta-cell glucose sensitivity from the response to intravenous glucose. J Clin Invest 68: 1456-1467

137. Campfield LA, Smith FJ (1990) Transient declines in blood glucose signal meal initiation. Int J Obes 14: 15-31

138. Campfield LA, Smith FJ, Rosenbaum M et al. (1996) Human eating: evidence for a physiological basis using a modified paradigm. Neurosci Biobehav Rev 20: 133-137

139. Smith FJ, Campfield LA (1993) Meal initiation occurs after experimental induction of transient declines in blood glucose. Am J Physiol 265: R1423-R1429

140. Smith GP, Jerome C, Cushin BJ et al. (1981) Abdominal vagotomy blocks the satiety effect of cholecystokinin in the rat. Science 213: 1036-1037

141. Campfield LA, Smith FJ (1990) Systemic factors in the control of food intake: evidence for patterns as signals.
In: Stricker EM (ed) Handbook of behavioral neurobiology: neurobiology of food and fluid intake. Plenum, New York, pp 183-206

142. Woods SC, Strubbe JH (1994) The psychobiology of meals. Psychon Bull Rev 1: 141-155

143. Gibbs J, Smith GP (1986) Satiety: the roles of peptides from the stomach and the intestine. Fed Proc 45: 1391-1395

144. Smith GP, Gibbs J (1992) The development and proof of the CCK hypothesis of satiety. In: Dourish CT, Cooper SJ, Iversen SD, Iversen LL (eds) Multiple cholecystokinin receptors in the CNS. Oxford Univ Press, Oxford, pp 166-182

145. Smith GP (1989) Animal models of human eating disorders. Ann NY Acad Sci 575: 63-74

146. Smith GP, Gibbs J (1994) Satiating effect of cholecystokinin. Ann NY Acad Sci 713: 236-241

147. Sankaran H, Deveney CW, Goldfine ID et al. (1979) Preparation of biologically active radioiodinated cholecystokinin for radioreceptor assay and radioimmunoassay. J Biol Chem 254: 9349-9351

148. Mantyh CR, Pappas TN, Vigna SR (1994) Localization of cholecystokinin A and cholecystokinin B/gastrin receptors in the canine upper gastrointestinal tract. Gastroenterology 107: 1019-1030

149. Figlewicz DP, Sipols AJ, Porte D, Jr. et al. (1989) IVT CCK inhibits food intake and gastric emptying in the baboon. Am J Physiol 256: R1313-R1317

150. Della-Fera MA, Baile CA (1980) CCK-octapeptide injected in CSF decreases meal size and daily food intake in sheep. Peptides 1: 51-54

151. Geary N, Smith GP (1982) Pancreatic glucagon and postprandial satiety in the rat. Physiol Behav 28: 313-322

152. Morley JE, Flood JF (1991) Amylin decreases food intake in mice. Peptides 12: 865-869

153. Rushing PA, Gibbs J, Geary N (1996) Brief, meal-contingent infusions of gastrin-releasing peptide 1-27 and neuromedian B-10 inhibit spontaneous feeding in rats. Physiol Behav 60: 1501-1504

154. Lin L, McClanahan S, York DA et al. (1993) The peptide enterostatin may produce early satiety. Physiol Behav 53: 789-794

155. Smith GP, Greenberg D, Corp E et al. (1990) Afferent information in the control of eating. Obesity: towards a molecular approach. Alan R. Liss, Inc., New York

156. West DB, Greenwood MRC, Marshall KA et al. (1987) Lithium chloride, cholecystokinin and meal patterns: evidence that cholecystokinin suppresses meal size in rats without causing malaise. Appetite 8: 221-227

157. Thiele TE, Van Dijk G, Campfield LA et al. (1997) Central infusion of GLP-1, but not leptin, produces conditioned taste aversions in rats. Am J Physiol 272: R726-R730

158. West DB, Fey D, Woods SC (1984) Cholecystokinin persistently suppresses meal size but not food intake in freefeeding rats. Am J Physiol 246: R776-R787

159. Figlewicz DP, Stein LJ, West D et al. (1986) Intracisternal insulin alters sensitivity to CCK-induced meal suppression in baboons. Am J Physiol 250: R856-R860

160. Riedy CA, Chavez M, Figlewicz DP et al. (1995) Central insulin enhances sensitivity to cholecystokinin. Physio Behav 58: 755-760

161. Figlewicz DP, Sipols AJ, Seeley RJ et al. (1995) Intraventricular insulin enhances the meal-suppressive efficacy of intraventricular cholecystokinin octapeptide in the baboon. Behav Neurosci 109: 1-3

162. Matson CA, Wiater M, Kuijper JL et al. (1997) Synergy between leptin and cholecystokinin (CCK) to control daily caloric intake. Peptides 18: 1275-1278 
163. Bray GA (1991) Obesity, a disorder of nutrient partitioning: the MONA LISA hypothesis. J Nutr 121: 1146-1162

164. Leibowitz SF (1985) Brain monoamines and peptides: role in the control of eating behavior. Federation Proc 45: 1396-1403

165. Leibowitz SF, Roossin P, Roosinn M (1984) Chronic norepinephrine injection into the hypothalamic paraventricular nucleus produces hyperphagia and increased body weight in the rat. Pharmacol Biochem Behav 21: 801-808

166. Paez X, Leibowitz SF (1993) Changes in extracellular PVN monoamines and macronutrient intake after idazoxan or fluoxetine injection. Pharmacol Biochem Behav 46: 933-941

167. Samanin R, Garattini S (1993) Neurochemical mechanism of action of anorectic drugs. Pharmacol Toxicol 73: 63-68

168. Blundell JE (1984) Serotonin and appetite. Neuropharmacology 23: 1537-1551

169. Blundell JE (1986) Serotonin manipulations and the structure of feeding behavior. Appetite 7 [Suppl] 39-56

170. Leibowitz SF, Weiss GF, Shor-Posner G (1988) Hypothalamic serotonin: pharmacological, biochemical, and behavioral analyses of its feeding-suppressive action. Clin Neuropharmacol 11: S51-S71

171. Davis R, Faulds D (1996) Dexfenfluramine. An updated review of its therapeutic use in the management of obesity. Drugs 52: 696-724

172. Thomas SA, Palmiter RD (1997) Thermoregulatory and metabolic phenotypes of mice lacking noradrenaline and adrenaline. Nature 387: 27-28

173. Turton MD, O'Shea D, Gunn I et al. (1996) A role for glucagon-like peptide- 1 in the central regulation of feeding. Nature 379: 69-72

174. Figlewicz DP, Nadzan AM, Sipols AJ et al. (1992) Intraventricular CCK-8 reduces single meal size in the baboon by interaction with type-A CCK receptors. Am J Physiol 263: R863-R867

175. Corwin RL, Corp ES, Gibbs J et al. (1992) Decreased behavioral effects of daily intracerebroventricular bombesin. Peptides 13: 1215-1218

176. van Dijk G, Thiele TE, Donahey JCK et al. (1996) Central infusion of leptin and GLP-1 (7-36) amide differentially stimulate c-Fos-like immunoreactivity in the rat brain. Am J Physiol 40: R1096-R1100

177. van Dijk G, Thiele TE, Seeley RJ et al. (1997) Glucagonlike peptide-1 and satiety (letter; comment). Nature 385: 214

178. Baldwin BA, de-la-Riva C, Ebenezer IS (1990) Effects of intracerebroventricular injection of dynorphin leumorphin and alpha neo-endorphin on operant feeding in pigs. Physiol Behav 48: 821-824

179. Nahon JL (1994) The melanin-concentrating hormone: from the peptide to the gene. Crit Rev Neurobiol 8: 221-262

180. Rossi M, Choi SJ, O'Shea D et al. (1997) Melanin-concentrating hormone acutely stimulates feeding, but chronic administration has no effect on body weight. Endocrinology 138: 351-355

181. Clark JT, Kalra PS, Crowley WR et al. (1984) Neuropeptide Y and human pancreatic polypeptide stimulate feeding behavior in rats. Endocrinology 115: 427-429

182. Stanley BG, Kyrkouli SE, Lampert S et al. (1986) Neuropeptide Y chronically injected into the hypothalamus: a powerful neurochemical inducer of hyperphagia and obesity. Peptides 7: 1189-1192

183. Fan W, Boston B, Kesterson R et al. (1997) Role of melanocortinergic neurons in feeding and the agouti obesity syndrome. Nature 385: 165-168
184. Rothwell N (1989) Central effects of CRF on metabolism and energy balance. Neurosci Biobehav Rev 14: 263-271

185. Schwartz M, Seeley R (1997) Neuroendocrine responses to starvation and weight loss. New Engl J Med 336: 1802-1811

186. Bray G (1992) Peptides affect the intake of specific nutrients and the sympathetic nervous system. Am J Clin Nutr 55: 265-271

187. Zarjevski N, Cusin I, Vetter R et al. (1993) Chronic intracerebroventricular neuropeptide-Y administration to normal rats mimics hormonal and metabolic changes of obesity. Endocrinology 133: 1753-1758

188. Paez X, Myers RD (1991) Insatiable feeding evoked in rats by recurrent perfusion of neuropeptide $\mathrm{Y}$ in the hypothalamus. Peptides 12: 609-616

189. van Dijk G, Bottone AE, Strubbe JH et al. (1994) Hormonal and metabolic effects of paraventricular hypothalamic administration of neuropeptide $Y$ during rest and feeding. Brain Res 660: 96-103

190. Stanley BG (1993) Neuropeptide Y in multiple hypothalamic sites controls eating hehavior, endocrine, and autonomic systems for energy balance. In: Colmers WF, Wahlestedt C (eds) The biology of neuropeptide $\mathrm{Y}$ and related peptides. Humana Press, Totowa, pp 457-509

191. Billington CJ, Briggs JE, Grace M et al. (1991) Effects of intracerebroventricular injection of neuropeptide $\mathrm{Y}$ on energy metabolism. Am J Physiol 260: R321-R327

192. Davies L, Marks JL (1994) Role of hypothalamic neuropeptide Y gene expression in body weight regulation. Am J Physiol 266: R1687-R1691

193. White JD, Kershaw M (1989) Increased hypothalamic neuropeptide $\mathrm{Y}$ expression following food deprivation. Mol Cell Neurosci 1: 41-48

194. Kalra SP, Dube MG, Sahu A et al. (1991) Neuropeptide Y secretion increases in the paraventricular nucleus in association with increased appetite for food. Proc Natl Acad Sci USA 88: 10931-10935

195. Bagdade JD, Bierman EL, Porte D, Jr. (1972) Counterregulation of basal insulin secretion during alcohol hypoglycemia in diabetic and normal subjects. Diabetes 21: 65-70

196. Boden G, Chen X, Mozzoli M et al. (1996) Effect of fasting on serum leptin in normal human subjects. J Clin Endocrinol Metab 81 (9): 3419-3423

197. McKibbin PE, Cotton SJ, McCarthy HD et al. (1992) The effect of dexamethasone on neuropeptide $\mathrm{Y}$ concentrations in specific hypothalamic regions. Life Sci 51: 1301-1307

198. Abe M, Saito M, Ikeda H et al. (1991) Increased neuropeptide $\mathrm{Y}$ content in the arcuato-paraventricular hypothalamic neuronal system in both insulin-dependent and non-insulin-dependent diabetic rats. Brain Res 539: 223-227

199. Wilding JPH, Gilbey SG, Bailey CJ et al. (1993) Increased neuropeptide-Y messenger ribonucleic acid (mRNA) and decreased neurotensin mRNA in the hypothalamus of the obese (ob/ob) mouse. Endocrinology 132: 1939-1944

200. Schwartz MW, Baskin DG, Bukowski TR et al. (1996) Specificity of leptin action on elevated blood glucose levels and hypothalamic neuropeptide $\mathrm{Y}$ gene expression in $o b / o b$ mice. Diabetes 45: 531-535

201. Stephens TW, Bashinski M, Bristow PK et al.(1995) The role of neuropeptide $\mathrm{Y}$ in the antiobesity action of the obese gene product. Nature 377: 530-534

202. Mercer JG, Moar KM, Rayner DV et al. (1997) Regulation of leptin receptor and NPY gene expression in hypo- 
thalamus of leptin-treated obese (ob/ob) and cold-exposed lean mice. FEBS Lett 402: 185-188

203. Campfield LA, Smith FJ, Gulsez Y et al. (1995) Recombinant mouse of protein: evidence for a peripheral signal linking adiposity and central neural networks. Science 269: 546-549

204. Halaas J, Boozer C, Blair-West J et al. (1997) Physiological response to long-term peripheral and central leptin infusion in lean and obese mice. Proc Natl Acad Sci 94: 8878-8883

205. Erickson JC, Clegg KE, Palmiter RD (1996) Sensitivity to leptin and susceptibility to seizures of mice lacking neuropeptide Y. Nature 381: 415-418

206. Erickson JC, Hollopeter G, Palmiter RD (1996) Attenuation of the obesity syndrome of $o b / o b$ mice by the loss of neuropeptide Y. Science 274: 1704-1707

207. Krahn DD, Gosnell BA (1988) Behavioral effects of corticotropin-releasing factor: localization and characterization of central effects. Brain Res 443: 63-69

208. Beyer HS, Matta SG, Sharp BM (1988) Regulation of the messenger ribonucleic acid for corticotropin-releasing factor in the paraventricular nucleus and other brain sites of the rat. Endocrinology 123: 2117-2123

209. Heinrichs SC, Menzaghi F, Pich EM et al. (1993) Corticotropin-releasing factor in the paraventricular nucleus modulate feeding induced by neuropeptide Y. Brain Res 611: 18-24

210. Arase K, York DA, Shimizu H et al. (1988) Effects of corticotropin-releasing factor on food intake and brown adipose tissue thermogenesis in rats. Am J Physiol 255: E255-E259

211. Hotta M, Shibasaki T, Yamauchi N et al. (1991) The effects of chronic central administration of corticotropin-releasing factor on food intake, body weight, and hypothalamic-pituitary-adrenocortical hormones. Life Sci 48: 1483-1491

212. Arase K, Shargill NS, Bray GA (1989) Effect of corticotropin releasing factor on genetically obese (fatty) rats. Physiol Behav 45: 565-570

213. Arase K, Shargill NS, Bray GA (1989) Effects of intraventricular infusion of corticotropin-releasing factor on VMH-lesioned obese rats. Am J Physiol 256: R751-R756

214. Glowa J, Gold P (1991) Corticotropin releasing hormone produces profound anorexigenic effects in the rhesus monkey. Neuropeptides 18: 55-61

215. McKibbin PE, McCarthy HD, Shaw P et al. (1992) Insulin deficiency is a specific stimulus to hypothalamic neuropeptide Y: a comparison of the effects of insulin replacement and food restriction in streptozotocin-diabetic rats. Peptides 13: 721-727

216. Brady LS, Smith MA, Gold PW et al. (1990) Altered expression of hypothalamic neuropeptide mRNAs in food restricted and food-deprived rats. Neuroendocrinology 52: 441-447

217. Ponsalle P, Srivastava LS, Uht RM et al. (1993) Glucocorticoids are required for food deprivation-induced increases in hypothalamic neuropeptide $\mathrm{Y}$ expression. J Neuroendocrinol 4: 585-591
218. Chavez M, Seeley RJ, Woods SC (1997) Adrenalectomy increases sensitivity to central insulin. Physiol Behav 62: 631-634

219. Zakrzewska KE, Cusin I, Sainsbury A et al. (1997) Glucocorticoids as counterregulatory hormones of leptin. Diabetes 46: 717-719

220. Remesar X, Rafecas I, FernandezLopez JA et al. (1997) Is leptin an insulin counter-regulatory hormone? FEBS Lett 402: 9-11

221. Strack AM, Sebastian RJ, Schwartz MW et al. (1995) Glucocorticoids and insulin: reciprocal signals for energy balance. Am J Physiol 268: 142-149

222. Schwartz MW, Strack A, Dallman MF (1998) Evidence that elevated plasma corticosterone levels are the cause of reduced hypothalamic corticotrophin releasing hormone gene expression in diabetes. Reg Peptides 72: 105112

223. Green PK, Wilkinson CW, Woods SC (1992) Intraventricular corticosterone increases the rate of body weight gain in underweight adrenalectomized rats. Endocrinology 130: 269-275

224. Shargill NS, Lupien JR, Bray GA (1989) Adrenalectomy in genetically obese ob/ob and $\mathrm{db} / \mathrm{db}$ mice increases the proton conductance pathway. Horm Metab Res 21: 463-467

225. Tokunaga K, Fukushima M, Lupien JR et al. (1989) Effects of food restriction and adrenalectomy in rats with VMH or PVH lesions. Physiol Behav 45: 1131-1137

226. Bray GA (1997) Progress in understanding the genetics of obesity. J Nutr 127: 940S-942S

227. Dallman MF, Strack AM, Akana SF et al. (1993) Feast and famine: critical role of glucocorticoids with insulin in daily energy flow. Front Neuroendocrinol 14: 303-347

228. Huszar D, Lynch C, Fairchild-Huntress Vet al. (1997) Targeted disruption of the melanocortin-4 receptor results in obesity in mice. Cell 88: 131-141

229. Pykalisto OJ (1975) Determinants of human adipose tissue lipoprotein lipase. Effect of diabetes and obesity on basal- and diet-induced activity. J Clin Invest 56: $1108-1117$

230. Taskinen MR, Nikkila EA (1979) Lipoprotein lipase activity of adipose tissue and skeletal muscle in insulin-deficient human diabetes. Relation to high-density and verylow-density lipoproteins and response to treatment. Diabetologia 17: 351-356

231. Taylor KG, Galton DJ, Holdsworth G (1979) Insulin-independent diabetes: a defect in the activity of lipoprotein lipase in adipose tissue. Diabetologia 16: 313-317

232. Schwartz MW, Marks J, Spols AJ et al. (1991) Central insulin administration reduces neuropeptide Y mRNA expression in the arcuate nucleus of food-deprived lean $(\mathrm{Fa} / \mathrm{Fa})$ but not obese (fa/fa) Zucker rats. Endocrinology 128: 2645-2647

233. Vettor R, Zarjevski N, Cusin I et al. (1994) Induction and reversibility of an obesity syndrome by intracerebroventricular neuropeptide $\mathrm{Y}$ administration to normal rats. Diabetologia 37: 1202-1208 